\title{
Sarcocystis neurona and related Sarcocystis spp. shed by opossums (Didelphis spp.) in South America
}

\author{
Sarcocystis neurona e Sarcocystis spp. relacionados, excretados por gambás \\ (Didelphis spp.) na América do Sul
}
Luís Fernando Pita Gondim* (1); Rodrigo Martins Soares²; Gastón Moré3,4; Rogério Fernando de Jesus; Horwald Alexander Bedoya Llano ${ }^{5}$

\author{
'Departamento de Anatomia, Patologia e Clínicas, Escola de Medicina Veterinária e Zootecnia, Universidade Federal da Bahia - UFBA \\ Salvador, BA, Brasil \\ ${ }^{2}$ Departamento de Medicina Preventiva e Saúde Animal, Faculdade de Medicina Veterinária e Zootecnia, \\ Universidade de São Paulo - USP, São Paulo, SP, Brasil \\ ${ }^{3}$ Consejo Nacional de Investigaciones Científicas y Técnicas - CONICET, Buenos Aires, Argentina \\ ${ }_{4}^{4}$ Laboratorio de Inmunoparasitología, Facultad de Ciencias Veterinarias, Universidad Nacional de La Plata, La Plata, \\ Buenos Aires, Argentina \\ ${ }^{5}$ Grupo de Investigación - GINVER, Facultad de Medicina Veterinaria, Corporación Universitaria Remington, Medellín, Colombia
}

How to cite: Gondim LFP, Soares RM, Moré G, de Jesus RF, Llano HAL. Sarcocystis neurona and related Sarcocystis spp. shed by opossums (Didelphis spp.) in South America. Braz J Vet Parasito/ 2021; 30(3): e006521. https://doi.org/10.1590/S1984-29612021059

\begin{abstract}
Protozoan parasites of the genus Sarcocystis are obligatory heteroxenous cyst-forming coccidia that infect a wide variety of animals and encompass approximately 200 described species. At least four Sarcocystis spp. (S. falcatula, S. neurona, S. lindsayi and S. speeri) use opossums (Didelphis spp.) as definitive hosts, and two of them, S. neurona and S. falcatula, are known to cause disease in horses and birds, respectively. Opossums are restricted to the Americas, but their distribution in the Americas is heterogeneous. Five Didelphis spp. are distributed in South America ( $D$. aurita, $D$. albiventris, $D$. marsupialis, $D$. imperfecta and $D$. pernigra) whereas just one opossum species (D. virginiana) is found in North America. Studies conducted in the last decades show that Sarcocystis spp., derived from South American Didelphis spp., have biological and genetic differences in relation to Sarcocystis spp. shed by the North American opossum D. virginiana. The aim of this review was to address the peculiar scenario of Sarcocystis species shed by South American opossums, with a special focus on diagnosis, epidemiology, and animal infections, as well as the genetic characteristics of these parasites.
\end{abstract}

Keywords: Sarcocystis neurona, Sarcocystis falcatula, marsupial, Sarcocystidae.

\section{Resumo}

Parasitos protozoários do gênero Sarcocystis são coccídios heteroxenos formadores de cistos, que infectam variadas espécies animais e compreendem cerca de 200 espécies descritas. Pelo menos quatro Sarcocystis spp. (S. falcatula, S. neurona, S. lindsayi e S. speeri) utilizam gambás (Didelphis spp.) como hospedeiros definitivos; e duas delas, S. neurona and S. falcatula são conhecidas por causarem doença em equinos e aves, respectivamente. Gambás didelfídeos são restritos ao continente americano, contudo são distribuídos de forma heterogênea nas Américas. Cinco Didelphis spp. são distribuídos na América do Sul (D. aurita, D. albiventris, D. marsupialis, $D$. imperfecta e $D$. pernigra), enquanto somente uma espécie (D. virginiana) é encontrada na América do Norte. Trabalhos conduzidos, nas últimas décadas, mostram que Sarcocystis spp. derivados de Didelphis spp. sulamericanos possuem diferenças biológicas e genéticas, quando comparados a Sarcocystis spp. excretados pelo gambá norte-americano $D$. virginiana. $O$ objetivo desta revisão é discutir a situação peculiar das espécies de Sarcocystis na América do Sul com um foco especial em diagnóstico, epidemiologia e infecções animais, assim como nas características genéticas desses parasitos.

Palavras-chave: Sarcocystis neurona, Sarcocystis falcatula, marsupial, Sarcocystidae. 


\section{Introduction}

Sarcocystis spp. are obligatory cyst-forming Apicomplexan parasites that infect a broad spectrum of animal hosts (Levine, 1986). Despite the large variety of described Sarcocystis spp., with more than 200 named species, complete life cycles are known for less than a quarter of them (Dubey et al., 2016). Among the Sarcocystis spp. infecting mammalian and avian hosts, two, that use opossums (Didelphis spp.) as definitive hosts, Sarcocystis falcatula and S. neurona, may cause serious disease in birds (Smith et al., 1987a, b) and horses (Dubey et al., 1991), respectively.

In recent years, numerous studies have shown that Sarcocystis spp. shed by South American opossums differ, in several aspects, from those found in North America (Acosta et al., 2018; Cesar et al., 2018; Gondim et al., 2019; Gondim et al., 2017; Valadas et al., 2016). Moreover, other species have been described and referred to, such as S. speeri (Dubey \& Lindsay, 1999), S. lindsayi (Dubey et al., 2001d) and S. falcatula-like (Dubey et al., 2000b). The differences and diversity of Sarcocystis spp. in South America may be partly related to the existence of five Didelphis spp. that may act as definitive hosts in this region (Didelphis aurita, D. albiventris, D. marsupialis, D. imperfecta and $D$. pernigra), contrasting with North America, where only one species of opossum is found (D. virginiana) (Cerqueira, 1985; Lemos \& Cerqueira, 2002). The diversity of South American fauna acting as intermediate hosts for Sarcocystis spp. is also higher than that of North America, which thus allows a potentially elevated degree of genetic recombination in South American opossums.

The aim of the current study was to review the published knowledge on Sarcocystis spp. from South American opossums as definitive hosts, with emphasis on diagnosis, epidemiology and genetic characteristics of these parasites. Special focus is given to studies about S. neurona and S. falcatula.

\section{Material and Methods}

Peer-reviewed papers on S. falcatula, S. falcatula-like, S. lindsayi, S. neurona and S. speeri involving South American animals were retrieved using the following databases: PubMed (2020, 2021), Scopus (2020, 2021), Web of Science $(2020,2021)$ and SciELO $(2020,2021)$, as well as recent textbooks. Meeting abstracts and conference proceedings were not included as references. Additional papers, not restricted to South American studies on Sarcocystis spp. derived from opossums, were added to help in relation to basic information on the parasites and Didelphis spp..

\section{Sarcocystis spp. using South American opossums as definitive hosts}

The most common and most widely distributed South American opossum is D. albiventris, especially in Argentina and Brazil (Cerqueira, 1985). The first studies conducted to identify Sarcocystis spp. sporocysts in Argentinian and Brazilian opossums were developed in collaboration with Dr. J.P. Dubey between 1998 and 2001 (Dubey et al., 2001d; Dubey et al., 1999b). Species identification in these studies was performed based on opossums' derived sporocyst infectivity to avian species, particularly budgerigars (Melopsittacus undulatus), and to immunodeficient mice, mostly gamma-interferon gene knockout mice (KO). Sarcocystis falcatula and $\mathrm{S}$. lindsayi are infective for birds while S. neurona and S. speeri are infective for mice (Dubey et al., 2016).

Among all Sarcocystis spp., S. neurona is probably the most studied species, because it causes neurological disease in horses and in some marine mammals. Sarcocystis spp. identified in opossums from Brazil and Argentina are summarized in Table 1. Most studies have aimed to isolate $S$. neurona from $D$. albiventris, but its frequency in South American opossums appears to be lower than expected (Dubey et al., 2016). Moreover, studies conducted in Argentinian D. albiventris detected sporocysts from S. falcatula in four samples (Dubey et al., 1999b) and S. speeri in two animals (Dubey et al., 2000e). Further characterization of two S. falcatula isolates from Argentina resulted in fatal infections for budgerigars (Dubey et al., 2000c). On the other hand, S. speeri induced non-fatal infections in KO mice and was transmitted via mouse tissues to D. virginiana (Dubey et al., 2000d). Similarly, the first studies conducted in Brazil identified S. falcatula-like in one specimen of D. albiventris (Dubey et al., 2000b), and later in one of D. marsupialis and eight of D. albiventris (Dubey et al., 2001c). Sarcocystis neurona was identified in two out of eight $D$. albiventris samples (Dubey et al., 2001 b) and S. lindsayi from one of D. albiventris (Dubey et al., 2001d). The opossum D. marsupialis from Brazil was identified as another definitive host for S. speeri (Dubey et al., 2000a).

Recently, several DNA samples derived from Sarcocystis spp. sporocysts, and cultured Sarcocystis spp., obtained from Brazilian opossums, were identified as S. falcatula-like due to their genetic characteristics and/or experimental infectivity to budgerigars (Gondim et al., 2017; Monteiro et al., 2013; Valadas et al., 2016). In summary, only two S. neurona isolates have been obtained from opossums in South America, both in D. albiventris from Brazil (Dubey et al., 2001b). 
Table 1. Identification of sporocysts and oocysts shed by opossums (Didelphis spp.) in Argentina and Brazil.

\begin{tabular}{|c|c|c|c|c|c|c|c|c|}
\hline Country & $\begin{array}{c}\text { State / } \\
\text { province }\end{array}$ & Host & $\begin{array}{l}\text { No. positive/no. } \\
\text { tested } \\
\text { (\% pos) }\end{array}$ & $\begin{array}{l}\text { Recovery of } \\
\text { sporocysts }\end{array}$ & Bioassay & $\begin{array}{l}\text { Molecular } \\
\text { biology }\end{array}$ & $\begin{array}{l}\text { Identified } \\
\text { species }\end{array}$ & Reference \\
\hline \multirow[t]{4}{*}{ Argentina } & $\begin{array}{l}\text { Buenos } \\
\text { Aires }\end{array}$ & D. albiventris & $4 / 4$ & $\begin{array}{l}\text { Intestinal } \\
\text { scraping }\end{array}$ & $\begin{array}{l}\text { Budgerigars } \\
(+)\end{array}$ & ND & S. falcatula & $\begin{array}{c}\text { (Dubey et al., } \\
\text { 1999b) }\end{array}$ \\
\hline & & & & & $\begin{array}{l}\mathrm{y}-\mathrm{IFN} \text { KO } \\
\text { mice }(-)\end{array}$ & & & \\
\hline & $\begin{array}{l}\text { Buenos } \\
\text { Aires }\end{array}$ & D. albiventris & $2 / 2^{A}$ & $\begin{array}{l}\text { Intestinal } \\
\text { scraping }\end{array}$ & $\begin{array}{l}\mathrm{y}-\text { IFN KO } \\
\text { mice }(+)\end{array}$ & ND & S. speeri & $\begin{array}{c}\text { (Dubey et al., } \\
\text { 2000e) }\end{array}$ \\
\hline & & & & & $\begin{array}{l}\text { nude Swiss } \\
\text { mice (-) }\end{array}$ & & & \\
\hline \multirow[t]{16}{*}{ Brazil } & São Paulo & D. albiventris & $1 / 3(33.3 \%)$ & $\begin{array}{l}\text { Intestinal } \\
\text { scraping }\end{array}$ & $\begin{array}{l}\text { Budgerigars } \\
\qquad(+)\end{array}$ & $\begin{array}{l}\text { ITS + RFLP } \\
\text { (Hinfl / } \\
\text { Dral), locus } \\
\text { 25/396 }\end{array}$ & $\begin{array}{l}\text { S. falcatula- } \\
\text { like }\end{array}$ & $\begin{array}{c}\text { (Dubey et al., } \\
\text { 2000b) }\end{array}$ \\
\hline & & & & & $\begin{array}{c}\text { y-IFN KO mice } \\
(-)\end{array}$ & $\begin{array}{l}\text { Large } \\
\text { subunit } \\
\text { ribosomal, } \\
\text { ITS1 }\end{array}$ & $\begin{array}{l}\text { Posteriorly } \\
\text { identified } \\
\text { as S. } \\
\text { lindsayi }\end{array}$ & $\begin{array}{c}\text { (Dubey et al., } \\
2001 \text { b) }\end{array}$ \\
\hline & São Paulo & D. marsupialis & $1 / \mathrm{NI}$ & $\begin{array}{l}\text { Intestinal } \\
\text { scraping }\end{array}$ & $\begin{array}{c}\text { Budgerigars } \\
(-)\end{array}$ & ND & S. speeri & $\begin{array}{c}\text { (Dubey et al., } \\
\text { 2000a) }\end{array}$ \\
\hline & & & & & $\begin{array}{c}\mathrm{y} \text {-IFN KO mice } \\
(+)\end{array}$ & & & \\
\hline & & & & & Nude mice (+) & & & \\
\hline & São Paulo & & $9 / \mathrm{NI}$ & $\begin{array}{l}\text { Intestinal } \\
\text { scraping }\end{array}$ & $\begin{array}{c}\text { Budgerigars } \\
(+)\end{array}$ & $\begin{array}{l}\text { ITS + RFLP } \\
\text { (Hinfl / }\end{array}$ & $\begin{array}{l}\text { S. falcatula- } \\
\text { like }\end{array}$ & $\begin{array}{l}\text { (Dubey et al., } \\
\text { 2001c) }\end{array}$ \\
\hline & & D. albiventris (8) & & & & $\begin{array}{l}\text { Dral), locus } \\
\text { 25/396, } \\
\text { large } \\
\text { subunit } \\
\text { ribosomal, } \\
\text { ITS1 }\end{array}$ & & \\
\hline & São Paulo & D. albiventris & $8 / \mathrm{NI}$ & $\begin{array}{l}\text { Intestinal } \\
\text { scraping }\end{array}$ & $\begin{array}{c}\mathrm{\gamma} \text {-IFN KO mice } \\
(+)\end{array}$ & $\begin{array}{l}\text { ITS + RFLP } \\
\text { (Hinfl / }\end{array}$ & & $\begin{array}{c}\text { (Dubey et al., } \\
2001 \mathrm{~b} \text { ) }\end{array}$ \\
\hline & & & & & & $\begin{array}{c}\text { Dral), locus } \\
25 / 396\end{array}$ & S. speeri & \\
\hline & $\begin{array}{l}\text { Rio de } \\
\text { Janeiro }\end{array}$ & D. aurita & $3 / 5(60 \%)$ & $\begin{array}{l}\text { Intestinal } \\
\text { scraping }\end{array}$ & $\begin{array}{c}\text { Budgerigars } \\
(+)\end{array}$ & ND & $\begin{array}{l}\text { S. lindsayi- } \\
\text { like }\end{array}$ & $\begin{array}{c}\text { (Stabenow et al., } \\
\text { 2008) }\end{array}$ \\
\hline & São Paulo & D. aurita (66 dead) & $\begin{array}{c}6 / 66(9.1 \%) \\
\text { D. aurita (dead) }\end{array}$ & $\begin{array}{l}\text { Intestinal } \\
\text { scraping, } \\
\text { fecal }\end{array}$ & ND & ND & $\begin{array}{l}\text { Sarcocystis } \\
\text { sp. }\end{array}$ & $\begin{array}{c}\text { (Casagrande et al., } \\
\text { 2009) }\end{array}$ \\
\hline & & $\begin{array}{l}\text { D. albiventris } \\
\text { (32 dead) }\end{array}$ & $\begin{array}{l}0 / 32(0 \%) \\
\begin{array}{l}\text { D. albiventris } \\
\text { (dead) }\end{array}\end{array}$ & $\begin{array}{l}\text { flotation (live } \\
\text { animals) }\end{array}$ & & & & \\
\hline & & D. aurita (28 alive) & $\begin{array}{c}2 / 28(7.1 \%) \\
\text { D. aurita (alive) }\end{array}$ & & & & & \\
\hline & & $\begin{array}{l}\text { D. albiventris } \\
\text { (05 alive) }\end{array}$ & $\begin{array}{c}0 / 5(0 \%) \\
\begin{array}{c}\text { D. albiventris } \\
\text { (alive) }\end{array}\end{array}$ & & & & & \\
\hline & $\begin{array}{l}\text { Rio de } \\
\text { Janeiro }\end{array}$ & D. aurita & $3 / 9(33.3 \%)$ & $\begin{array}{l}\text { Intestinal } \\
\text { scraping }\end{array}$ & $\begin{array}{l}\text { Budgerigars } \\
(+)\end{array}$ & ND & S. lindsayi & $\begin{array}{c}\text { (da Silva } \\
\text { Stabenow et al., } \\
\text { 2012) }\end{array}$ \\
\hline & $\begin{array}{l}\text { Rio Grande } \\
\text { do Sul }\end{array}$ & $\begin{array}{l}\text { D. albiventris, } \\
\text { D. aurita }\end{array}$ & $27 / \mathrm{NI}$ & $\begin{array}{l}\text { Intestinal } \\
\text { scraping, } \\
\text { fecal } \\
\text { flotation }\end{array}$ & ND & $\begin{array}{l}\text { SAG2, } \\
\text { SAG3, } \\
\text { SAG4 }\end{array}$ & $\begin{array}{l}\text { S. falcatula- } \\
\text { like }\end{array}$ & $\begin{array}{l}\text { (Monteiro et al., } \\
\text { 2013) }\end{array}$ \\
\hline
\end{tabular}

References: $\mathrm{ND}$ = not done; $\mathrm{NI}$ = not informed; ${ }^{\mathrm{A}}=$ Both opossum samples were previously identified as having S. falcatula sporocysts (Dubey et al., 1999b) 
Table 1. Continued...

\begin{tabular}{|c|c|c|c|c|c|c|c|c|}
\hline Country & $\begin{array}{l}\text { State / } \\
\text { province }\end{array}$ & Host & $\begin{array}{c}\text { No. positive/no. } \\
\text { tested } \\
\text { (\% pos) }\end{array}$ & $\begin{array}{l}\text { Recovery of } \\
\text { sporocysts }\end{array}$ & Bioassay & $\begin{array}{c}\text { Molecular } \\
\text { biology }\end{array}$ & $\begin{array}{l}\text { Identified } \\
\text { species }\end{array}$ & Reference \\
\hline & São Paulo & Didelphis sp. & $25 / \mathrm{NI}$ & $\begin{array}{l}\text { Intestinal } \\
\text { scraping }\end{array}$ & ND & $\begin{array}{l}\text { SAG2, } \\
\text { SAG3, } \\
\text { SAG4, } \\
\text { ITS1, CytB }\end{array}$ & & $\begin{array}{c}\text { (Valadas et al., } \\
\text { 2016) }\end{array}$ \\
\hline & \multirow[t]{2}{*}{ Bahia } & D. albiventris (16) & $0 / 39$ & \multirow[t]{2}{*}{$\begin{array}{l}\text { Intestinal } \\
\text { scraping }\end{array}$} & $\underset{(+)}{\text { Budgerigars }}$ & $\begin{array}{l}\text { SAG2, } \\
\text { SAG3, } \\
\text { SAG4, }\end{array}$ & $\begin{array}{l}\text { S. falcatula- } \\
\text { like }\end{array}$ & $\begin{array}{c}\text { (Gondim et al., } \\
\text { 2017) }\end{array}$ \\
\hline & & $\begin{array}{c}\text { D. aurita/ } \\
\text { marsupialis (23) }\end{array}$ & $\begin{array}{l}9 \text { positive } \\
\text { samples from } \\
\text { independent } \\
\text { study of São } \\
\text { Paulo state }\end{array}$ & & $\begin{array}{c}\mathrm{y}-\mathrm{IFN} \text { KO mice } \\
(-)\end{array}$ & $\begin{array}{l}\text { ITS1, CytB, } \\
\text { locus } \\
25 / 396\end{array}$ & & \\
\hline & \multirow[t]{2}{*}{$\begin{array}{l}\text { Rio de } \\
\text { Janeiro }\end{array}$} & \multirow[t]{2}{*}{ D. aurita } & \multirow[t]{2}{*}{$8 / 13(61.5 \%)$} & $\begin{array}{l}\text { Intestinal } \\
\text { scraping, } \\
\text { fecal }\end{array}$ & $\underset{(+)}{\text { Budgerigars }}$ & \multirow[t]{2}{*}{$\begin{array}{c}\text { ITS + RFLP } \\
\text { (Hinfl / } \\
\text { Dral), ITS }\end{array}$} & $\begin{array}{l}\text { S. falcatula- } \\
\text { like }\end{array}$ & (Gallo et al., 2018) \\
\hline & & & & flotation & Nude mice (-) & & $\begin{array}{c}\text { Maybe S. } \\
\text { lindsayi in } \\
\text { one sample }\end{array}$ & \\
\hline & \multirow[t]{2}{*}{ São Paulo } & D. albiventris (1) & \multirow[t]{2}{*}{$12 / \mathrm{NI}$} & \multirow[t]{2}{*}{$\begin{array}{l}\text { Intestinal } \\
\text { scraping }\end{array}$} & $\begin{array}{l}\text { Budgerigars } \\
\qquad(+)\end{array}$ & $\begin{array}{l}\text { SAG2, } \\
\text { SAG3, } \\
\text { SAG4, }\end{array}$ & \multirow[t]{2}{*}{$\begin{array}{l}\text { S. falcatula- } \\
\text { like }\end{array}$} & \multirow[t]{2}{*}{ (Cesar et al., 2018) } \\
\hline & & $\begin{array}{c}\text { D. aurital } \\
\text { marsupialis (11) }\end{array}$ & & & & $\begin{array}{c}\text { ITS1, CytB, } \\
18 \mathrm{~S}\end{array}$ & & \\
\hline & Bahia & $\begin{array}{l}\text { D. aurita/ } \\
\text { marsupialis }\end{array}$ & $1 / 1$ & $\begin{array}{l}\text { Intestinal } \\
\text { scraping }\end{array}$ & $\begin{array}{c}\text { Budgerigars } \\
\qquad(+)\end{array}$ & $\begin{array}{c}\text { SAG2, } \\
\text { SAG3, } \\
\text { SAG4, } \\
\text { ITS1, 18S, } \\
\text { Cox1, locus } \\
25 / 396\end{array}$ & $\begin{array}{l}\text { S. falcatula- } \\
\text { like }\end{array}$ & $\begin{array}{c}\text { (Gondim et al., } \\
\text { 2019) }\end{array}$ \\
\hline
\end{tabular}

References: ND = not done; NI = not informed; A = Both opossum samples were previously identified as having S. falcatula sporocysts (Dubey et al., 1999b)

\section{Genetic characteristics of Sarcocystis spp. shed by South American opossums}

Overview on molecular identification of Sarcocystis spp.

The taxonomy of the genus Sarcocystis is based on the morphological characteristics of the sarcocysts, life cycle characteristics (host specificity) and molecular data (Dubey et al., 2016; Lindsay et al., 1995).

However, the morphology of mature sarcocysts, the structures typically found in the natural intermediate hosts of the parasite, such as size, shape, and cyst wall structure, may be shared by several closely related species (Gjerde, 2013). Moreover, Sarcocystis species might be inaccurately described because the structural characteristics of sarcocysts may vary according to the method of fixation, the degree of development (age) of the sarcocyst and the type of tissue in which it is found, among other factors (Dubey et al., 2016).

Since each species of Sarcocystis may have a particular spectrum of hosts, knowledge on infectivity to intermediate, definitive and eventual aberrant hosts, might offer information of great value for identification of the parasite (Butcher et al., 2002; Cutler et al., 1999; Dubey \& Lindsay, 1998). Full knowledge of the host specificity of the parasite is often difficult to obtain, since it depends on experimental infections or on detection of the parasite in naturally infected animals, in wild or domestic fauna.

Thus, molecular data, especially those based on phylogenies, have become mandatory for identification of species of the genus Sarcocystis (Gjerde, 2014; Gjerde et al., 2017; Morrison et al., 2004). Molecular data have made it possible to discriminate between species that had previously been considered synonymous, by means of morphological analysis or expansion of the knowledge of their host spectrum. Moreover, S. falcatula and S. neurona were determined to definitely be distinct species by means of molecular differentiation (Marsh et al., 1999). As additional example, molecular analysis on a sarcocyst in muscle tissue, identified herring gull (Larus argentatus, 
order Charadriiformes) as a new intermediate host for S. wobeseri; this Sarcocystis species had exclusively been found in the order Anseriformes (geese and ducks) (Prakas et al., 2011).

Molecular analyses on viruses and bacteria have become significantly enhanced through next-generation sequencing (NGS)-based technologies, in which complete genomes are evaluated within a few hours. On the other hand, technologies based on NGS are less commonly used for routine investigation of molecular diversity in eukaryotes, due to the large size and complexity of their genomes, along with the high costs involved (Maljkovic Berry et al., 2020). Thus, traditional approaches based on the Sanger sequencing method, directed to complete or partial gene segments, have been widely used to access the diversity of eukaryotic organisms, including protozoa of the genus Sarcocystis.

The nuclear genome sequences encoding ribosomal RNA products and the genes encoding mitochondrial products in the genome of this organelle are the molecular markers most used for identifying Sarcocystis species (Gjerde, 2013, 2016). The gene encoding the small ribosomal unit (18S rDNA) has been identified for most Sarcocystis spp. (Dubey et al., 2016). The $18 \mathrm{~S}$ rDNA gene alternates highly conserved and highly variable domains (Morrison et al., 2004; Morrison \& Ellis, 1997; Ogedengbe et al., 2016), which makes it possible to design of universal primers that are complementary to conserved regions (helices) that flank segments of high variability (loops). Therefore, this favors detection and identification of unknown species belonging to the genus.

Although $18 \mathrm{~S}$ rDNA is widely used for molecular identification of Sarcocystis spp., closely related species are occasionally almost identical at this locus, as is the case of $S$. falcatula and $S$. neurona. These species had erroneously been regarded as synonymous because of minimal differences at this locus (Dame et al., 1995; Fenger et al., 1995). In fact, 18 S rDNA gene is not sufficiently variable to differentiate between certain Sarcocystis species that use birds as intermediate hosts (Olias et al., 2010; Prakas et al., 2013). However, because 18S rDNA is considered to be a universal marker for molecular identification, it is highly recommended that new descriptions of species of the genus Sarcocystis should include nucleotide sequences of this gene. Thus, $18 \mathrm{~S}$ sequences of new Sarcocystis spp. will enable phylogenetic comparisons and reconstructions with homologous sequences that are available in public-access databases (Dubey et al., 2016; Morrison et al., 2004).

With phylogenetic resolution slightly superior to that of $18 \mathrm{~S}$ rDNA, the gene encoding the large ribosomal unit (28S rDNA) (Mugridge et al., 1999) has also been used to identify Sarcocystis, although much less frequently. While a search at GenBank using the terms [18S + Sarcocystis] brings 2166 items, the same search with the terms [28S + Sarcocystis] brings 231 items (NCBI, 2020).

The mitochondrial gene encoding cytochrome c oxidase subunit I (COI) is a molecular marker that has shown good phylogenetic resolution for discrimination of living organisms among different taxa (Pentinsaari et al., 2016), including those among the Sarcocystis genus. The COI genetic sequences have been successfully used to discriminate among Sarcocystis spp., using ruminants as intermediate hosts (Gjerde, 2013). However, the differences identified at this locus are minimal among Sarcocystis spp. that use birds or carnivorous mammals as intermediate hosts (Gjerde et al., 2017).

As mentioned above, the genes encoding ribosomal RNA and the genes encoding mitochondrial products may not be variable enough to discriminate between certain Sarcocystis spp. In these cases, markers with higher evolutionary rates, such as the first and second internal transcribed spacers (ITS1 and ITS2, respectively), can be used (Marsh et al., 1999). The ITS1 and ITS2 sequences are located between coding sequences of the ribosomal units $18 \mathrm{~S}$ and $5.8 \mathrm{~S}$ and between $5.8 \mathrm{~S}$ and 28S, respectively (Hillis \& Dixon, 1991). Public-access databases have a much larger number of ITS1 sequences than ITS2 for Sarcocystis spp., and thus the first locus has been used most to discriminate between species (Watthanakaiwan et al., 2017). As in other ribosomal loci, the advantages of using ITS1 and ITS2 are the universality and sensitivity of the assays that aim towards these loci, since the ribosomal loci are present in several copies within the eukaryote genome (Alvarez \& Wendel, 2003). However, because ITS1 and ITS2 have much higher evolutionary rates than 18S rDNA, COI and $28 \mathrm{~S}$ rDNA, phylogenetic studies using these markers need to only contain very similar organisms. ITS sequences from distant organisms cannot be unambiguously aligned because many insertions and deletions are present, which greatly reduces the reliability of the phylogenetic alignment (Prakas et al., 2013). For this reason, ITS-based phylogenies for the genus Sarcocystis should not be rooted with organisms of other genera. The ITS1-based phylogeny of species of Toxoplasmatinae could not be rooted because the sequences could not be aligned against the outgroup (Ellis et al., 1999). ITS1 sequences of Sarcocystis spp. typically range from 600 to 1000, while ITS1 of Toxoplasmatinae species encompass about 500 nucleotides in length. 
From the above, it is clear that more than one gene is needed to produce a species phylogeny for the Sarcocystis genus, in order to obtain consistent identification.

\section{Genetic characterization of Sarcocystis spp. excreted by didelphid opossums in Brazil}

Marsupials of the genus Didelphis, which are exclusive to the Americas, are definitive hosts of at least four morphologically and very similar Sarcocystis spp.: S. neurona, S. falcatula, S. lindsayi and S. speeri. In addition to the morphological similarity, these four species are closely related from a phylogenetic point of view, although they can be differentiated using molecular methods.

Due to the high similarity between S. falcatula and S. neurona at $18 \mathrm{~S}$ rDNA, it was initially suggested that these species were synonymous (Dame et al., 1995). However, through comparing ITS1 sequences, Marsh et al. (1999) demonstrated that S. falcatula and S. neurona were, in fact, organisms with significant divergence and could be unequivocally differentiated through this marker. They also identified considerable diversity of ITS1 among samples of S. falcatula, thus indicating that this species should constitute a heterogeneous population.

Sarcocystis speeri and S. neurona are infectious species for mammals and have high molecular similarity. Although a few morphological differences between these two species have been identified, these agents are practically identical at molecular level (Dubey et al., 2015b). Complete ITS1 sequences from these two agents have up to $99.7 \%$ identity (only 3 SNPs difference), which strongly suggests that they are synonymous species.

Sarcocystis lindsayi and S. falcatula are species that are infectious for birds and, contrary to what is observed between S. neurona and S. speeri, have much more extensive molecular differences. At ITS1, S. lindsayi has 93.3\% and $92.6 \%$ identity with S. falcatula and S. speeri, respectively, although at $28 \mathrm{~S}$, these three species are almost identical (Dubey et al., 2001d). The only isolate of S. lindsayi that has been molecularly identified was from budgerigars (Melopsittacus undulates) experimentally infected with Didelphis albiventris sporocysts from Brazil (reference).

Sarcocystis spp. excreted by opossums of the genus Didelphis have intraspecific diversity. Tanhauser et al. (1999) and Marsh et al. (1999) demonstrated that some North American isolates of Sarcocystis spp. derived from opossum sporocysts were distinct from both $S$. neurona and S. falcatula. Through sequencing ITS1, these isolates were found to be $96.0-96.8 \%$ and $95.5-96.4 \%$ similar to S. neurona and S. falcatula, respectively (Tanhauser et al., 1999). Although at that time $S$. lindsayi had not yet been described, it is now well known that these isolates are even more divergent from S. lindsayi. Later on, isolates that were equally divergent at ITS1 from both S. neurona and S. falcatula were detected in Brazil. These isolates had proved infectious for budgerigars, and they were named Sarcocystis falcatula-like organisms (Dubey et al., 2001c). Since then, the S. falcatula-like ITS1 genotype has been systematically found in isolates from Brazil, both in budgerigars experimentally infected with opossum sporocysts (Cesar et al., 2018; Gondim et al., 2017) and in organs of naturally infected wild birds (Acosta et al., 2018; Konradt et al., 2017).

The S. falcatula ITS1 alleles described in the studies by Marsh et al. (1999) and Tanhauser et al. (1999) have never been detected in Sarcocystis spp. from South America, but S. falcatula-like ITS1 alleles were recently described in the United States in naturally infected rainbow lorikeets (Verma et al., 2018). Further studies are needed to test the hypothesis that this diversity is due to heterogeneity of ITS1 copies. It is well known that the ribosomal locus is present in more than one copy in the apicomplexan nuclear genome (Morrison \& Ellis, 1997; Mugridge et al., 2000). Nevertheless, no sequence data with a mixture of sequences compatible with the simultaneous occurrence of the two alleles have yet been described. The allelic diversity of S. falcatula-like ITS1 has been described, but not at the nucleotide positions that consistently differentiate between S. falcatula and S. falcatula-like alleles (Marsh et al., 1999).

PCR and restriction endonuclease digestion (PCR-RFLP) of the locus JNB 33/54 were formerly used in the differential diagnosis of S. neurona and S. falcatula (Tanhauser et al., 1999). The endonuclease Dral is able to cut the 1100 bp JNB 33/54 PCR products of S. neurona isolates, but not from S. falcatula. Conversely, Hinfl does not cut the 1100 bp product of S. neurona, but cuts those from S. falcatula. However, PCR-RPLP of the locus JNB 33/54 of some isolates of opossum derived Sarcocystis sp. were cut by both endonucleases and such isolates have been identified as S. falcatula-like. Using this molecular method, Gallo et al. (2018) demonstrated for the first time that S. falcatula-like could be shed by the Didelphis aurita.

There are only two reports on molecular descriptions of S. neurona in intermediate hosts in Brazil. These include a naturally infected cat with meningoencephalitis (Hammerschmitt et al., 2020) and naturally infected horses with EPM (Henker et al., 2020). Both studies were conducted in the state of Rio Grande do Sul, Brazil. The molecular identification of the parasite in these studies revealed ITS1 alleles with less than $98 \%$ similarity to the 
homologous sequences of S. neurona and S. speeri that had been described up to that time. Moreover, phylogenetic reconstructions have shown that the parasites were related to S. neurona (Hammerschmitt et al., 2020; Henker et al., 2020). The isolate from the cat (Hammerschmitt et al., 2020) and isolates of S. falcatula and S. neurona were also compared at genes encoding surface antigens and the results corroborated the information obtained using ITS1. Interestingly, this feline sample was revealed to be identical, at ITS1 and surface antigen genes, to sporocysts of Sarcocystis spp. detected in didelphid opossums in Brazil (Valadas et al., 2016).

Evidence of S. neurona infection in cats was also reported by Lucio et al. (2021). In this study, the authors described the natural occurrence of $S$. neurona muscular sarcocysts in cats without Sarcocystis-associated disease. However, in spite of the fact that sarcocysts were unequivocally identified in skeletal muscle of cats, the molecular identification of the parasites was performed by using genetic fragment with insufficient discriminatory power to differentiate species within the genus Sarcocystis.

The results from Hammerschmitt et al. (2020) and Henker et al. (2020) suggest that more than one strain of S. neurona also occurs in the Americas. While the S. neurona genotype detected in cats and horses in Brazil has not yet been detected elsewhere, alleles relating to the other $S$. neurona strains have been detected across the America, in D. virginiana (Dubey \& Lindsay, 1998) and D. albiventris (Dubey et al., 2001b), as well as in many intermediate hosts (Dubey et al., 2015a).

After identifying the molecular diversity of Sarcocystis spp. detected in 50 samples of intestinal scraps from didelphid opossums in Brazil, Valadas et al. (2016) found ITS1 sequences from S. falcatula-like, but not from S. falcatula. In addition to S. falcatula-like, they identified four alleles of ITS1, among which one was identical to the ITS1 of S. neurona detected in a cat by Hammerschmitt et al. (2020) in Brazil. The other three alleles were phylogenetically related, but distant from the four known species of opossum derived Sarcocystis. These three alleles are possibly from a still-unknown species of Sarcocystis.

The intraspecific diversity of Sarcocystis spp. shed by didelphid opossums has been identified through multilocus analyses. Multilocus characterizations of $S$. falcatula-like were performed after analyses on three loci encoding surface antigens: SAG2, SAG3 and SAG4. From SAG-based multilocus analyses on isolates obtained from budgerigars experimentally infected with opossum sporocysts (Cesar et al., 2018; Gondim et al., 2017) and from naturally infected birds (Acosta et al., 2018; Konradt et al., 2017), four SAG2 alleles, five SAG3 alleles and four SAG4 alleles have been identified in S. falcatula-like. Interestingly, each SAG-based phylogeny demonstrates the occurrence of two families (clades) of alleles with significant inter-group diversity (Figure 1). These alleles seem to randomly recombine, but the biological implications of the SAG-admixture, such as pathogenicity or infectivity to the host, are yet to be clarified.

The diversity of $S$. falcatula-like organisms revealed through multilocus analysis contrasts with the results from similar investigations carried out using samples of S. neurona detected in different mammals in North America (Barbosa et al., 2015; Rejmanek et al., 2010; Wendte et al., 2010). All the samples of S. neurona investigated by these authors were identical at ITS1 and were almost identical at the SAG2, SAG3 and SAG4 alleles. Rejmanek et al. (2010) found no variability in SAG2 and only one polymorphic site in SAG4, between isolates from different mammal species such as horses, didelphids, felines and sea otters. Among marine mammals, the variability of S. neurona in SAG3 and SAG4 (Barbosa et al., 2015; Wendte et al., 2010) is much less than that found among S. falcatula-like detected in parakeets experimentally infected with sporocysts from Didelphis spp. (Cesar et al., 2018; Gondim et al., 2017). While only seven polymorphic sites in SAG3 and one in SAG4 (in about 1000 nucleotides analyzed) discriminated 37 isolates of S. neurona sampled by Barbosa et al. (2015), up to 30 polymorphic sites were detected in SAG3 and 17 in SAG4 (in about 300-400 nucleotides analyzed) among different isolates of S. falcatula-like obtained from experimentally infected parakeets.

Didelphid opossums originated in South America and the genus possibly expanded its range to North America before the rise of the Panamanian land bridge was completed by 3.1-2.7 Ma and the Great American Biotic Interchange took place (Dias \& Perini, 2018). A new separation between these continental masses occurred after the construction of the Panama Canal at the end of $19^{\text {th }}$ century. Dias \& Perini (2018) also suggested that, after a northern South American origin for the genus, climatic-driven modifications in Neotropical environments during the late Pliocene and early Pleistocene favored the dispersion to new ecosystems triggering the emergence of new lineages. Two highly similar lineages of S. falcatula and two highly similar lineages of S. neurona may have recently emerged. Molecular clock tests would help to date when the differentiation between these strains occurred and whether such a tiny divergence would be related in time to the migratory movements of marsupial species across the Americas. 

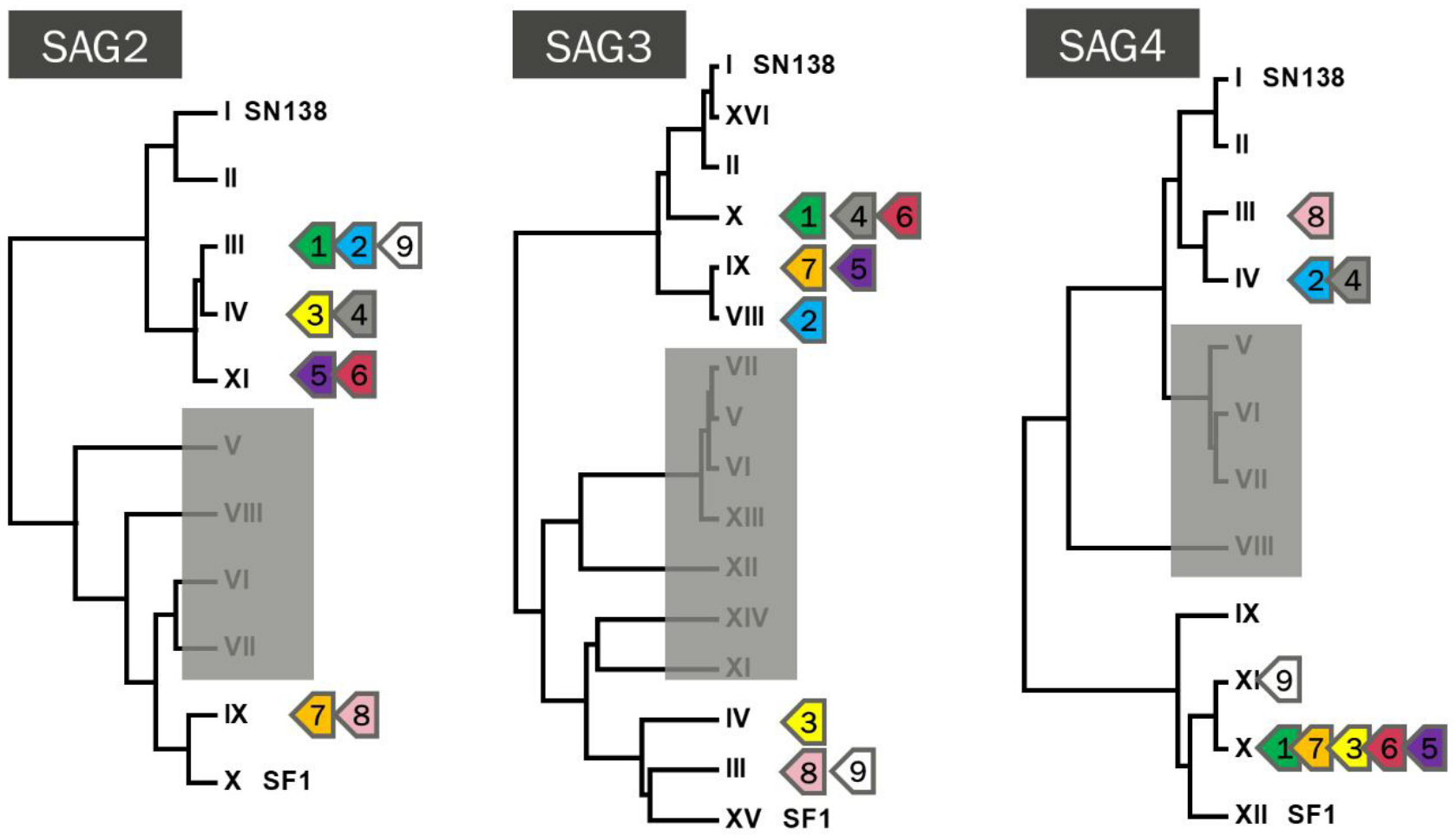

Figure 1. Published in Gondim et al. (2019). Dendrograms on SAG2, SAG3 and SAG4 genotypes from Sarcocystis spp. that use Brazilian Didelphis spp. as definitive hosts, as proposed by Monteiro et al. (2013) and Valadas et al. (2016). Arrows 1 to 7 correspond to Sarcocystis spp. genotypes derived from budgerigars that were experimentally infected with Didelphis spp. sporocysts (Cesar et al., 2018; Gondim et al., 2017). Arrow 8 identifies a genotype of S. falcatula isolated from a naturally infected bare-faced ibis (Phimosus infuscatus) (Konradt et al., 2017). Arrow 9 represents a S. falcatula-like isolate from Bahia (Gondim et al., 2019) and those observed in Magellanic penguins (Acosta et al., 2018). SN138 (Lindsay et al., 2004) and SF1 (Marsh et al., 1997) are reference strains of Sarcocystis neurona and Sarcocystis falcatula, respectively. Alleles in shaded boxes correspond to genotypes identified in opossum-derived sporocysts that have not been associated with S. falcatula so far.

Studies on population genetics or experimental infections are needed in order to test the hypothesis that the two molecular types of $S$. neurona and the two molecular types of $S$. falcatula are in fact distinct species. Likewise, further studies are needed to assess the epidemiological or biological relevance of the extensive intraspecific diversity detected in S. falcatula-like organisms.

\section{Confusion on classification between Didelphis aurita and D. marsupialis}

Six species of Didelphidae opossums have been identified in the Americas. Whereas only one species (D. virginiana) is found in North America, five Didelphis spp. exist in South America, which have been grossly divided into white-eared opossums ( $D$. albiventris, $D$. pernigra and $D$. imperfecta) and black-eared opossums $(D$. aurita and D. marsupialis) (Cerqueira, 1985; Lemos \& Cerqueira, 2002). Combination of morphological and molecular studies on Didelphis spp. has significantly aided in differentiation and characterization of each separate species (Cervantes et al., 2010; Sousa et al., 2012).

Some published reports on Sarcocystis spp. derived from South American opossums seem to show confusion regarding the classification of $D$. aurita and $D$. marsupialis, which are morphologically similar, but have different geographical distributions. In a study conducted in southeastern Brazil, S. speeri sporocysts were reported from intestinal scraps of $D$. marsupialis that inhabited the vicinities of the city of São Paulo (Dubey et al., 2000a). Sporocysts derived from an opossum referred to as D. marsupialis (Dubey et al., 2000a; Dubey et al., 2001b) were used in a second study (Dubey et al., 2001c) in which S. falcatula-like in D. marsupialis from São Paulo was reported. It is noteworthy that $D$. marsupialis does not exist in the state of São Paulo: this species has only been described in the northern and central regions of the country (Cerqueira, 1985; Lemos \& Cerqueira, 2002). The findings of 
Sarcocystis spp. in D. marsupialis reported in the state of São Paulo were probably related to $D$. aurita, which is the only black-eared opossum in this state.

Due to morphological similarities between $D$. aurita and $D$. marsupialis, some authors have referred to black-eared opossums as $D$. aurita/D. marsupialis, given that precise differentiation between these species requires molecular analysis, which has poor availability (Gondim et al., 2017).

\section{Diagnosis of Equine Protozoal Myeloencephalitis (EPM) and S. neurona in horses}

Equine protozoal myeloencephalitis (EPM) was first diagnosed in Brazil several decades ago. In one of the first published studies, 77 thoroughbred horses in the state of São Paulo, including animals with neurological disease, abortion and without clinical signs, were examined for T. gondii antibodies. Based on the serological results, the authors assumed that clinical signs were attributable to toxoplasmosis (Macruz et al., 1975). Another study reported the presence of protozoal organisms in the spinal cord of a 10-year-old horse (Lombardo de Barros et al., 1986); however, at that time, the causative agent was not elucidated. A few years later, two horses were diagnosed with neurological disease caused by Sarcocystis sp. infection, given that mature schizonts and merozoites were associated with the lesions (Masri et al., 1992); one of the horses was born and reared in Brazil, while the other was born in Argentina and reared in Brazil. Protozoal organisms were labelled in CNS tissues by means of immunohistochemistry (IHC) using a polyclonal serum against S. cruzi as the primary antibody. However, the authors assumed that S. neurona was the causative agent of the lesions (Masri et al., 1992), since S. neurona had been isolated and classified from a horse with EPM in the United States (Dubey et al., 1991).

In a retrospective study conducted in Minas Gerais, formalin-fixed fragments from the central nervous system (CNS) of 187 horses and 16 mules that had been placed in storage between 1942 and 2005 were screened for lesions (Paixão et al., 2007). Inflammation was observed in 54 samples that were processed for immunohistochemical analysis using a primary antibody against S. neurona that was provided by a laboratory in the USA (Paixão et al., 2007). Severe multifocal nonsuppurative encephalitis was observed in a seven-year-old thoroughbred horse that had been admitted to the Animal Hospital in 2004 and was treated with corticosteroid (dexamethasone), DMSO, vitamin B1 and fluid therapy. The clinical condition of the horse progressed to paralysis of the limbs and the animal was euthanized (Paixão et al., 2007).

In Argentina, many anecdotal results circulate among horse breeders and veterinarians. However, there has only been one recent confirmed EPM case report, on a 12-year-old mare from Buenos Aires Province that presented asynchronous walking and bilateral stringhalt. It was decided to euthanize the animal because of severe clinical progression and lack of response to treatment. Microscopic lesions were observed in brain and spinal cord samples and IHC analysis revealed the presence of $S$. neurona meronts and free merozoites. PCR-RFLP analysis showed a specific S. neurona restriction pattern in brain samples (Moré et al., 2019).

In a retrospective study in Brazil, formalin-fixed and paraffin-embedded tissues from 38 horses that presented myelitis, encephalitis and/or meningitis were examined for EPM (Henker et al., 2020). Thirteen of the horses tested were diagnosed as having EPM based on the following criteria: mononuclear perivascular cuffing, inflammatory infiltrate of eosinophils and multinucleated giant cells. Immunostaining using a polyclonal serum for S. neurona was positive in 11 horses, and partial nucleotide sequences of ITS1 from 6 horses presented the best match with S. neurona (Henker et al., 2020).

So far, no in vitro isolation of $S$. neurona has been obtained from affected horses in South America. In a study conducted on Brazilian opossums (D. albiventris), Sarcocystis sporocysts were detected and shipped to the US and processed by means of mouse bioassay. The parasite isolated in cell culture from murine tissues was classified as S. neurona (Dubey et al., 2001b). No subsequent studies on this S. neurona isolate have been published.

\section{Serological studies on South American horses}

Indirect or serological diagnostic techniques are an important tool for identifying exposure to $S$. neurona in horses, as well as for aiding in EPM monitoring and clinical intervention (Dubey et al., 2016). The Western blot or Immunoblot test (IB), using a full extract of merozoite antigen, was the first assay developed for qualitative detection of antibodies against S. neurona in horses (Granstrom et al., 1993). Antibodies against S. neurona were attached to immune dominant antigens (IDA) both in serum and CSF (cerebral spinal fluid) samples. However, the results were only semi-quantitative (i.e. negative, weak-positive and positive). This test has been extensively used 
in North America, but because it is laborious and requires significant expertise for accurate interpretation, several other assays for identifying and quantifying antibodies against $S$. neurona have subsequently been developed (Dubey et al., 2015a). Among these assays, the immunofluorescent antibody test (IFAT) and various enzyme-linked immunosorbent assays (ELISAs) are widely used for EPM diagnosis and seroepidemiological studies in South America (Table 2). In the absence of cultured S. neurona isolates derived from South American animals, serological studies on horses have been conducted with merozoites from North American strains or proteins (recombinant or crude) of the parasite (Table 2).

An IFAT for S. neurona was developed and consisted of whole-cell culture-derived merozoites (Duarte et al., 2003). It allowed detection of antibodies to S. neurona surface antigens, but some of these antigens are probably shared among different species of the genus Sarcocystis (Dubey et al., 2016). Therefore, use of IFAT requires validation and proper definition of cutoff titers in order to avoid false-positive results due to antibodies against Sarcocystis spp. other than S. neurona (Dubey et al., 2016).

Several ELISAs have been developed using S. neurona merozoite surface antigens (SnSAGs), mainly expressed as recombinant proteins (Dubey et al., 2015a). The largest serological study performed on South American horses was based on SnSAG4 ELISA (Hoane et al., 2006). However, due to the possibility of false-positive results from using a single antigen protein and through variation of SnSAGs among isolates, an improved SnSAG ELISA was developed, based on three recombinant surface antigens (Reed et al., 2013).

The majority of seroepidemiological studies performed on South American equids have been conducted in Brazil, and have been carried out in several states, distributed in the five main regions of the country (North, Northeast, Center-West, Southeast and South) (Table 2).

Combining all the published seroepidemiological surveys conducted in South America, more than 5000 horses have been tested for $S$. neurona antibodies by means of different techniques. The most frequently used test in these studies was IFAT, followed by ELISAs and, at a lower proportion, by IB (Table 2). Samples tested using IFAT have shown a range of seropositivity, from 2.8 to $84.1 \%$, with most studies showing values around $40 \%$ (Table 2 ). IFAT has been conducted with cutoffs between 1:20 and 1:80. Even in some studies using low cutoffs (1:25 or 1:50), the frequencies of antibodies in horses were below 50\% (Antonello et al., 2015; Cazarotto et al., 2016; Koch et al., 2019; Portella et al., 2017; Spohr et al., 2018). It is noteworthy that serological studies conducted using SnSAG4 ELISA reported higher antibody frequencies (higher than $60 \%$ in most regions) than studies conducted using IFAT (Table 2). On the other hand, the few populational studies conducted using IB showed moderate positivity ranging from 26.1 to $35.6 \%$ (Dubey et al., 1999a; Moré et al., 2014). As previously mentioned, the studies conducted by means of S. neurona ELISA and IFAT presented the possibility of detection of some false-positive results, due to horse antibodies against other Sarcocystis spp. In addition, the studies using combinations of tests or IB as confirmatory after a positive IFAT or ELISA result showed a lower number of "true positive" samples (Borges et al., 2017; Valença et al., 2019). A study performed in Argentina using IB revealed a twofold seropositivity rate (odds ratio 2.27) in horses with neurological signs, compared with horses without clinical signs (39.2\% versus $22.1 \%$, respectively), thus suggesting that S. neurona might be implicated in the occurrence of neurological disorders (Moré et al., 2014). In the same study, 71\% of the samples showed reactivity to protein bands with a relative motility of $30 \mathrm{kDa}$ (which includes the antigens SnSAG1 and SnSAG4). This result is comparable what was obtained using SnSAG4 ELISA in Brazil and could represent the presence of antibodies against other Sarcocystis spp., rather than against S. neurona.

Serological studies performed in Brazil with precolostral foal serum samples have suggested that there is potential for vertical transmission of Sarcocystis spp. in horses (Antonello et al., 2016; Pivoto et al., 2014). However, Antonello et al. (2016) found that 7.4\% (14/189) of their foal samples were seropositive according to IFAT at low antibody titers, and the same samples were negative using IB. Pivoto et al. (2014) detected that $6.6 \%(12 / 181)$ of their samples were positive according to an ELISA using total lysate antigen (TLA) from S. neurona. Altogether, these results are controversial, since some seropositive foals were born from seronegative mares, and the specificity of the detected antibodies is doubtful. Identification of Sarcocystis spp. in tissues from aborted or newborn foals could help to confirm the vertical transmission hypothesis.

Other equids from Brazil have also been tested for antibodies against S. neurona. In a study using 47 mule samples processed using IFAT (SN37R at 1:25 dilution), seropositivity of 17\% was recorded (Borges et al., 2017). In the same study, from 500 horse serum samples, 112 tested positive through IFAT, and only 33 were confirmed through rSnSAG2/4/3 S. neurona ELISA (Table 2). A subset of 28 samples (from the 33 ELISA positive samples) were tested using IB, and a reaction against S. neurona IDA was only detected in 15 samples (Borges et al., 2017). These 
Table 2. Serological studies on Sarcocystis neurona in South American horses

\begin{tabular}{|c|c|c|c|c|c|c|c|}
\hline Country & State/Province & $\begin{array}{l}\text { No. } \\
\text { tested }\end{array}$ & $\begin{array}{c}\text { No. } \\
\text { positive } \\
(\%)\end{array}$ & Test & Antigen /strain & Cut-off & Reference \\
\hline \multirow[t]{2}{*}{ Argentina } & Chaco & 76 & $\begin{array}{c}27 \\
(35.5)\end{array}$ & Immunoblot & TLA/SN3 & - & $\begin{array}{c}\text { (Dubey et al., } \\
\text { 1999c) }\end{array}$ \\
\hline & $\begin{array}{c}\text { Buenos Aires } \\
\text { (531),Cordoba (51), } \\
\text { Santa Fe (11), La } \\
\text { Pampa (8), Corrientes } \\
\text { (5), Santiago del } \\
\text { Estero (4), San Juan } \\
\text { (4), Neuquen (1), Entre } \\
\text { Rios (1), unknown (24) }\end{array}$ & 640 & $\begin{array}{c}167 \\
(26.1)\end{array}$ & Immunoblot & TLA/SN3 & - & $\begin{array}{l}\text { (Moré et al., } \\
\text { 2014) }\end{array}$ \\
\hline \multirow[t]{18}{*}{ Brazil } & Alagoas & 427 & $\begin{array}{c}12 \\
(2.8)\end{array}$ & $\begin{array}{l}\text { IFAT and } \\
\text { immunoblot }\end{array}$ & $\begin{array}{c}\text { Merozoite/ SN37R } \\
\text { TLA/SN3 }\end{array}$ & $\begin{array}{c}1: 80 \\
-\end{array}$ & $\begin{array}{c}\text { (Valença et al., } \\
\text { 2019) }\end{array}$ \\
\hline & Bahia & 9 & $\begin{array}{c}7 \\
(77.8)\end{array}$ & SnSAG4 ELISA & SnSAG4/SN3 & $25 \%$ & $\begin{array}{l}\text { (Hoane et al., } \\
\text { 2006) }\end{array}$ \\
\hline & Goiás & 15 & $\begin{array}{c}9 \\
(60)\end{array}$ & SnSAG4 ELISA & SnSAG4/SN3 & $25 \%$ & $\begin{array}{c}\text { (Hoane et al., } \\
\text { 2006) }\end{array}$ \\
\hline & Mato Grosso & 28 & $\begin{array}{c}15 \\
(53.6)\end{array}$ & SnSAG4 ELISA & SnSAG4/SN3 & $25 \%$ & $\begin{array}{l}\text { (Hoane et al., } \\
\text { 2006) }\end{array}$ \\
\hline & Mato Grosso & 500 & $\begin{array}{c}104 \\
(20.8)\end{array}$ & IFAT and & Merozoite/ SN37R & $1: 25$ & $\begin{array}{c}\text { (Borges et al., } \\
\text { 2017) }\end{array}$ \\
\hline & & & $\begin{array}{l}33 \\
(6)^{a}\end{array}$ & rSnSAG ELISA & rSnSAG2/4/3 & $10 \%$ & \\
\hline & Mato Grosso do Sul & 11 & $\begin{array}{c}9 \\
(81.8)\end{array}$ & SnSAG4 ELISA & SnSAG4/SN3 & $25 \%$ & $\begin{array}{l}\text { (Hoane et al., } \\
\text { 2006) }\end{array}$ \\
\hline & Minas Gerais & 10 & $\begin{array}{c}9 \\
(90)\end{array}$ & SnSAG4 ELISA & SnSAG4/SN3 & $25 \%$ & $\begin{array}{l}\text { (Hoane et al., } \\
\text { 2006) }\end{array}$ \\
\hline & Minas Gerais & 506 & $\begin{array}{c}117 \\
(23.09)\end{array}$ & IFAT & Merozoite/SN37R & $1: 80$ & $\begin{array}{l}\text { (Ribeiro et al., } \\
\text { 2016) }\end{array}$ \\
\hline & Paraná & 146 & $\begin{array}{c}88 \\
(60.3)\end{array}$ & SnSAG4 ELISA & SnSAG4/SN3 & $25 \%$ & $\begin{array}{c}\text { (Hoane et al., } \\
\text { 2006) }\end{array}$ \\
\hline & Paraná & 100 & $\begin{array}{c}42 \\
(42)\end{array}$ & IFAT & Merozoite/ SN37R & $1: 50$ & $\begin{array}{l}\text { (Koch et al., } \\
\text { 2019) }\end{array}$ \\
\hline & Rio Grande do Sul & 2 & $\begin{array}{c}1 \\
(50)\end{array}$ & SnSAG4 ELISA & SnSAG4/SN3 & $25 \%$ & $\begin{array}{l}\text { (Hoane et al., } \\
\text { 2006) }\end{array}$ \\
\hline & Rio Grande do Sul & 189 & $\begin{array}{c}57 \\
(33.86)\end{array}$ & IFAT & Merozoite/ SN37R & $1: 50$ & $\begin{array}{c}\text { (Antonello et al., } \\
\text { 2015) }\end{array}$ \\
\hline & Rio Grande do Sul & $\begin{array}{c}195 \\
\text { (M and PF) }\end{array}$ & $\begin{array}{l}\text { M } 159 \\
(84.1)\end{array}$ & IFAT & Merozoite/ SN37R & $M=1: 50$ & $\begin{array}{c}\text { (Antonello et al., } \\
\text { 2016) }\end{array}$ \\
\hline & & & $\begin{array}{l}\text { PF } 14 \\
(7.4)\end{array}$ & & & $P F=1: 25$ & \\
\hline & Rio Grande do Sul & $\begin{array}{c}181 \\
(\mathrm{M} \text { and } \mathrm{PF})\end{array}$ & $\begin{array}{l}\text { M } 61 \\
(33.7)\end{array}$ & ELISA & TLA/SN37R & $\mathrm{El}>1.2$ & $\begin{array}{l}\text { (Pivoto et al., } \\
\text { 2014) }\end{array}$ \\
\hline & & & $\begin{array}{l}\text { PF } 12 \\
(6.6)\end{array}$ & & & & \\
\hline & $\begin{array}{c}\text { Rio Grande do Sul and } \\
\text { Paraná }\end{array}$ & 197 & $\begin{array}{c}71 \\
(36)\end{array}$ & IFAT & Merozoite/ SN37R & $1: 50$ & $\begin{array}{l}\text { (Portella et al., } \\
\text { 2017) }\end{array}$ \\
\hline
\end{tabular}

References: TLA= total lysate antigen. $\mathrm{ND}=$ not described. $\mathrm{El}=\mathrm{ELISA}$ index. $\mathrm{M}=$ mares. $\mathrm{PF}$ : pre-colostral foals. ${ }^{\mathrm{a}}=$ confirmed by ELISA. * $=$ absorbance units. 
Table 2. Continued...

\begin{tabular}{|c|c|c|c|c|c|c|c|}
\hline Country & State/Province & $\begin{array}{l}\text { No. } \\
\text { tested }\end{array}$ & $\begin{array}{l}\text { No. } \\
\text { positive } \\
(\%)\end{array}$ & Test & Antigen /strain & Cut-off & Reference \\
\hline & Rondônia & 192 & $\begin{array}{c}162 \\
(84.4)\end{array}$ & SnSAG4 ELISA & SnSAG4/SN3 & $25 \%$ & $\begin{array}{l}\text { (Hoane et al., } \\
\text { 2006) }\end{array}$ \\
\hline & Roraima & 303 & $\begin{array}{c}141 \\
(43.2)\end{array}$ & IFAT & Merozoite/SN37R & $1: 25$ & $\begin{array}{l}\text { (Spohr et al., } \\
\text { 2018) }\end{array}$ \\
\hline & Roraima & 213 & $\begin{array}{c}86 \\
(40.4)\end{array}$ & IFAT & Merozoite/SN-138 & $1: 80$ & $\begin{array}{c}\text { (Gomes et al., } \\
2019 \text { ) }\end{array}$ \\
\hline & Santa Catarina & 24 & $\begin{array}{c}11 \\
(45.8)\end{array}$ & SnSAG4 ELISA & SnSAG4/SN3 & $25 \%$ & $\begin{array}{c}\text { (Hoane et al., } \\
\text { 2006) }\end{array}$ \\
\hline & Santa Catarina & 174 & $\begin{array}{c}72 \\
(41.37)\end{array}$ & IFAT & Merozoite/SN37R & $1: 50$ & $\begin{array}{c}\text { (Cazarotto et al., } \\
\text { 2016) }\end{array}$ \\
\hline & São Paulo & 101 & $\begin{array}{c}36 \\
(35.6)\end{array}$ & Immunoblot & TLA/SN3 & - & $\begin{array}{c}\text { (Dubey et al., } \\
\text { 1999a) }\end{array}$ \\
\hline & São Paulo & 513 & $\begin{array}{c}348 \\
(67.8)\end{array}$ & SnSAG4 ELISA & SnSAG4/SN3 & $25 \%$ & $\begin{array}{l}\text { (Hoane et al., } \\
\text { 2006) }\end{array}$ \\
\hline & São Paulo & 116 & $\begin{array}{c}27 \\
(23.8)\end{array}$ & IFAT & Merozoite/SN-138 & $1: 80$ & $\begin{array}{c}\text { (Oliveira et al., } \\
\text { 2017) }\end{array}$ \\
\hline & Unknown & 11 & $\begin{array}{c}10 \\
(90.9)\end{array}$ & SnSAG4 ELISA & SnSAG4/SN3 & $25 \%$ & $\begin{array}{l}\text { (Hoane et al., } \\
\text { 2006) }\end{array}$ \\
\hline \multirow[t]{2}{*}{ Colombia } & Córdoba & 73 & $\begin{array}{c}48 \\
(65.7)\end{array}$ & ELISA/ND & ELISA/ND & $100 *$ & $\begin{array}{c}\text { (Calderón et al. } \\
\text { 2014) }\end{array}$ \\
\hline & Bogotá & 1 & 1 & Immunoblot & TLA/SN3 & - & $\begin{array}{c}\text { (Medina \& } \\
\text { Oliver, 2003) }\end{array}$ \\
\hline
\end{tabular}

References: TLA= total lysate antigen. $\mathrm{ND}=$ not described. $\mathrm{EI}=\mathrm{ELISA}$ index. $\mathrm{M}=$ mares. $\mathrm{PF}$ : pre-colostral foals. ${ }^{\mathrm{a}}=$ confirmed by ELISA. * = absorbance units.

results showed that there was a lack of or poor agreement among the serological methods and suggested that cross-reactivity of equid serum samples against Sarcocystis spp. was potentially occurring.

A seroepidemiological study performed on serum samples from 329 donkeys (Equus asinus) detected antibody frequencies of 3\% using IFAT and $21 \%$ using a direct agglutination test (SAT), at 1:40 and 1:50 cutoffs, respectively. In both tests, the antigens consisted of merozoites from a North American strain of S. neurona (SN3) (Gennari et al., 2016). The correlation between the two tests used was poor ( $k a p p a=0.051)$, and the potential for cross-reaction with antibodies generated by other Sarcocystis spp. in the donkeys tested could not be ruled out (Gennari et al., 2016).

Recently, a serological comparative study was conducted on 409 horse samples from Brazil, which was performed using IFAT (starting dilution of 1:20) with antigens derived from a Brazilian strain of S. falcatula-like (Sarco-BA1) and from a North American strain of S. neurona (SN138). Out of all the samples, $10.5 \%$ and $17.1 \%$ were reactive to S. falcatula-like and S. neurona antigens, respectively. The poor agreement observed between the two IFATs $(\mathrm{k}=0.364)$ indicated that the horses were exposed to more than one Sarcocystis species. Some IFAT-positive samples were also tested using IB (using the same isolates as antigens) and showed cross-reactivity to proteins in the range of 16 and $30 \mathrm{kDa}$ (Borges-Silva et al., 2020).

The relatively higher frequency of isolation of $S$. falcatula-like in Brazil, and the detection of horse serum samples reacting to antigens derived from North American S. neurona isolates, open the question about the real "specificity" of serological results targeted to S. neurona antibodies in South America. It is highly probable that South American horses are exposed to S. falcatula-like, as well as to S. neurona, S. lindsayi and S. speeri, which are also shed by opossums. In addition, horses are intermediate hosts (harboring muscle cysts) of Sarcocystis bertrami (syn. Sarcocystis fayeri), which uses canids as definitive hosts (Zeng et al., 2018). Combination of serological methods could help to increase specificity, as also would combining these with direct detection methods for Sarcocystis spp. 
in horse tissues. The potential implication of other Sarcocystis spp. shed by South American opossums in horse neurological disorders and EPM remains uncertain.

\section{Sarcocystis neurona infection or exposure in domestic carnivores and in wildlife}

Few serological investigations have been performed to detect antibodies against S. neurona in domestic carnivores in South America. This is probably explained, in part, by the lack of clinical reports of $S$. neurona infection in South American dogs and cats, except for one recent report of clinical S. neurona infection in a Brazilian cat (Hammerschmitt et al., 2020). Poor access to serological tests for S. neurona in most South American countries is another factor that may hamper serological investigations of the parasite in these countries.

Two studies using canine serum samples were conducted in the Brazilian states of Paraná (Koch et al., 2019) and Bahia (Oliveira et al., 2020). In both studies, low frequencies of seropositivity for S. neurona were found using IFAT, with 7/100 (7\%) and 12/353 (3.4\%) positive animals, respectively, with antibody titers reaching 100 (Oliveira et al., 2020) and 500 (Koch et al., 2019), thus indicating low exposure of these animals to the pathogen (Table 3). No association with neurological signs was observed by Koch et al. (2019), who used 35 animals with neurological signs and 65 asymptomatic animals $(p=0.69)$. In the study conducted in Bahia, none of the animals selected for the study presented any clinical signs (Oliveira et al., 2020).

In three serological studies performed on cats in Brazil, low frequencies of antibodies against S. neurona were observed in the animals examined. In the first study, 502 cats were tested using SAT (S. neurona agglutination test), and all of them were seronegative (Dubey et al., 2002). It is worth mentioning that all the cats tested were from urban areas and they probably had lower exposure to $S$. neurona sporocysts than cats from rural areas. Subsequently, two studies using IFAT found that $4 \%$ (Meneses et al., 2014) and 7\% (Koch et al., 2019) of the cats

Table 3. Serological studies on Sarcocystis neurona in South American domestic carnivores and wildlife.

\begin{tabular}{|c|c|c|c|c|c|c|c|c|}
\hline & Country & State/region & Species & $\begin{array}{l}\text { No. } \\
\text { tested }\end{array}$ & $\begin{array}{l}\text { No. } \\
\text { positive } \\
(\%)\end{array}$ & Serology & Cut-off & Reference \\
\hline \multirow[t]{5}{*}{$\begin{array}{l}\text { Domestic } \\
\text { Carnivores }\end{array}$} & Brazil & São Paulo & Cat & 502 & $0(0 \%)$ & SAT & $1: 50$ & $\begin{array}{c}\text { (Dubey et al., } \\
\text { 2002) }\end{array}$ \\
\hline & & Bahia & Cat & 272 & $\begin{array}{c}11 \\
(4.04 \%)\end{array}$ & IFAT & $1: 25$ & $\begin{array}{l}\text { (Meneses et al., } \\
\text { 2014) }\end{array}$ \\
\hline & & Paraná & Dog & 100 & $7(7 \%)$ & IFAT & $1: 50$ & \multirow{2}{*}{$\begin{array}{c}\text { (Koch et al., } \\
\text { 2019) }\end{array}$} \\
\hline & & & Cat & 100 & $5(5 \%)$ & IFAT & $1: 50$ & \\
\hline & & Bahia & Dog & 353 & $12(3.39)$ & IFAT & $1: 25$ & $\begin{array}{l}\text { (Oliveira et al., } \\
\text { 2020) }\end{array}$ \\
\hline \multirow[t]{4}{*}{ Wildlife } & Brazil & São Paulo & $\begin{array}{c}\text { Capybara } \\
\text { (Hydrochoerus } \\
\text { hydrochaeris) }\end{array}$ & 63 & $2(3.17 \%)$ & IFAT & $1: 25$ & $\begin{array}{c}\text { (Valadas et al., } \\
\text { 2010) }\end{array}$ \\
\hline & & Mato Grosso & $\begin{array}{c}\text { Jaguar } \\
\text { (Panthera onca) }\end{array}$ & 11 & $8(72.7 \%)$ & IFAT & $1: 25$ & $\begin{array}{c}\text { (Onuma et al., } \\
\text { 2014) }\end{array}$ \\
\hline & & Paraná & $\begin{array}{c}\text { Red-tailed Amazon } \\
\text { parrot } \\
\text { (Amazona } \\
\text { brasiliensis) }\end{array}$ & 51 & $0(0 \%)$ & IFAT & $1: 5$ & $\begin{array}{c}\text { (Sato et al., } \\
\text { 2020) }\end{array}$ \\
\hline & Peru & Ica & $\begin{array}{l}\text { South American } \\
\text { fur seal } \\
\text { (Arctocephalus } \\
\text { australis) }\end{array}$ & 29 & $0(0 \%)$ & IFAT & $1: 40$ & $\begin{array}{c}\text { (Jankowski et al., } \\
\text { 2015) }\end{array}$ \\
\hline
\end{tabular}

References: SAT: Sarcocystis agglutination test; IFAT: Indirect Fluorescent Antibody Test. 
were seropositive. Although seropositivity was similar in these two studies, Koch et al. (2019) obtained a maximum titer of 100, while Meneses et al. (2014) observed 800 as the maximum titer (Table 3). As in dogs, no association with neurological signs was reported for the seropositive cats.

In a recent study, a 1.7-year-old domestic cat, which presented anorexia, dyspnea, pleural effusion, positive test for feline leukemia virus (FeLV) and a presumptive diagnosis of mediastinal lymphoma, was treated with vincristine, prednisolone and cyclophosphamide (Hammerschmitt et al., 2020). Twenty-one days after the first clinical presentation, the cat also showed neurological signs, that progressed to death. Histopathological examination revealed meningoencephalitis in the brain and cerebellum, associated with parasites resembling S. neurona. The parasites observed were labelled immunohistochemically using polyclonal serum against S. neurona. PCR was performed using DNA extracted from the feline brain. Nucleotide sequencing of ITS1 and SAG loci, as shown in detail in section 4.1, showed that the parasite detected, which was regarded as S. neurona, was genetically different from strains isolated in North America (Hammerschmitt et al., 2020).

Studies on S. neurona in South American wildlife are also scarce. Little is known about cross-reactivity among Sarcocystis spp. excreted by Didelphis spp., or among other species of Sarcocystis (de Jesus et al., 2019). The pathogenicity to wildlife species of Sarcocystis spp. derived from opossums is also largely unknown (Onuma et al., 2014; Valadas et al., 2010). Few intermediate hosts of S. neurona have been confirmed in North America (Dubey et al., 2015a), which makes investigations on wild species less common. Serological agglutination tests on a related parasite, Toxoplasma gondii, are frequently used for wildlife species (Kornacka et al., 2016), but the S. neurona direct agglutination test (SAT) has only rarely been used in serological investigations. Large quantities of parasites are required as antigens for agglutination tests: in the case of $S$. neurona, multiplication of merozoites in cell cultures is poor in comparison with related parasites (Ellison et al., 2001), which may hamper preparation of antigen for SAT. Most seroepidemiological surveys for $S$. neurona in wildlife have been carried out using IFAT with specific or cross-reactive secondary antibodies (Jankowski et al., 2015; Onuma et al., 2014; Sato et al., 2020).

In Peru, antibodies against S. neurona were investigated in South American fur seals (Arctocephalus australis) from a marine protected area, as part of a health evaluation on this animal species (Jankowski et al., 2015). Despite mortality caused by S. neurona in sea otters (Enhydra lutris nereis) in the North Pacific (Miller et al., 2010), susceptibility or exposure of South American fur seals to the pathogen was not confirmed in any of the 29 animals tested (Jankowski et al., 2015). In Brazil, two apparently healthy adult capybaras (Hydrochoerus hydrochaeris) (2/63) tested positive through IFAT for S. neurona antibodies in the state of São Paulo (Valadas et al., 2010). Also in Brazil, antibodies reactive to $S$. neurona were detected in 8/11 jaguars in the state of Mato Grosso (Onuma et al., 2014). Despite the small sample size, the finding of high antibody titers reactive to $S$. neurona in these felids is suggestive of environmental contamination of the parasite sporocysts in the region studied (Onuma et al., 2014).

In North America, there has been a single report of S. neurona infection in an avian species. S. neurona tissue cysts were detected in brown-headed cow birds (Molothrus ater) and merozoites of the cultured parasite were infective to opossums (D. virginiana) and to gamma-interferon gene knockout mice (Mansfield et al., 2008). Limited investigations have been conducted on S. neurona in South American birds. In the state of Paraná, southern Brazil, 51 red-tailed Amazon parrots (Amazona brasiliensis) were tested for the parasite using IFAT and none of them were seropositive for S. neurona (Sato et al., 2020). So far, there have not been any confirmed cases of infection by S. neurona in South American birds.

\section{Sarcocystis falcatula, S. falcatula-like and sarcocystosis in birds}

Birds become infected with S. falcatula through ingesting food or water contaminated with feces from infected opossums. Another route of infection consists of consumption of paratenic hosts such as flies and cockroaches that are carrying sporocysts (Clubb \& Frenkel, 1992).

Reports of S. falcatula or related species in birds in South America are scarce and are often associated with Old World species. The first reported outbreak of acute pulmonary sarcocystosis in birds occurred in a zoological collection in Belo Horizonte, Brazil (Ecco et al., 2008). Eight psittacines belonging to three different species and one pigeon were found dead and had exhibited no previous clinical signs. At necropsy, pulmonary congestion and edema were the most common findings. Immunohistochemical analysis confirmed the presence of mature schizonts and merozoites, diagnosed as S. falcatula, in the capillaries of the lungs, heart, liver and spleen of the birds. Another outbreak in a zoo in Brazil was documented a year later (Godoy et al., 2009). A total of 47 psittacines housed in a bird park in Foz do Iguaçu, state of Paraná, died within a 15-month period as a result of Sarcocystis sp. infection. 
Using histopathology, immunohistochemistry, electron microscopy and bioassay, S. falcatula was indicated as the cause of death. Although fatalities have only affected a few New World psittacine birds, mortality among Old World species has been found to be higher. The latter were more susceptible to the pulmonary form of sarcocystosis.

Respiratory alterations are the predominant abnormalities associated with S. falcatula and S. falcatula-like infection in captive or free-living birds (Dubey et al., 2001a; Hillyer et al., 1991; Suedmeyer et al., 2001; Verma et al., 2018; Villar et al., 2008; Wünschmann et al., 2010). However, a few cases of these protozoa causing encephalitis in wild birds have also been described (Siegal-Willott et al., 2005; Wünschmann et al., 2009). In Brazil, a young free-ranging bare-faced ibis (Phimosus infuscatus) was clinically examined because of wing paralysis and mild motor incoordination. The bird died four days after admission to a veterinary center and at necropsy presented multifocal to coalescing soft yellowish areas in the brain. The results from histopathological and molecular analyses revealed necrotizing meningoencephalitis in cerebellum and brainstem caused by S. falcatula (Konradt et al., 2017). This was the first record of necrotizing meningoencephalitis in a native South American bird caused by S. falcatula.

There is limited knowledge on the occurrence of S. falcatula or related species in naturally infected birds without clinical disease. Molecular evidence of a species closely related to $S$. falcatula was detected in the carcasses of 16 Magellanic penguins (Spheniscus magellanicus) that were rescued on the coast of Brazil (Acosta et al., 2018). Given that parasite DNA sequences were obtained in muscle tissue samples, these authors suggested that the genetic material originated from tissue cysts, which are structures characteristic of the chronic phase of infection, and hence, it was unlikely that the parasite was the cause of death.

\section{Conclusions and future directions}

The great majority of the studies examined, on Sarcocystis spp. shed by South American opossums, were restricted to Brazil and Argentina. In most of these studies, S. falcatula or S. falcatula-like species were identified in $D$. aurita and $D$. albiventris. In a few reports, it seems that $D$. aurita was mistakenly identified as $D$. marsupialis, because this latter species does not inhabit the geographical area where it was classified.

Up to the time of conclusion of the current review, no viable isolate of S. neurona had been obtained in South America. For this reason, serological tests for S. neurona in South American animals have been made using North American strains of the parasite. There is no gold-standard serological test for EPM caused by S. neurona in South America due to the lack of a serum panel of truly S. neurona-infected horses.

Viable S. falcatula-like merozoites have been obtained in Brazil and used in serological tests and in experimental infections. Brazilian horses have been found to be reactive to $S$. falcatula-like antigen; however, it is unknown whether horses are naturally exposed to $S$. falcatula-like or whether the seropositivity in horses resulted from cross-reactivity with other Sarcocystis spp.

The scenario of Sarcocystis spp. shed by opossums in South America is very peculiar, in comparison with North America. Therefore, future investigations should be conducted in several directions, as follows: 1) the role of $D$. albiventris, $D$. aurita and other Didelphis spp. (D. marsupialis, D. imperfecta and D. pernigra) as definitive hosts of S. neurona, S. falcatula and related species should be investigated; 2 ) intermediate hosts of Sarcocystis spp. derived from South American opossums should be identified; 3) viable South American isolates of S. neurona and related Sarcocystis spp. should be obtained for diagnosis and molecular studies; 4) it is crucial to investigate whether South American horses are susceptible to other Sarcocystis spp. derived from opossums, besides S. neurona; and 5) the serodiagnosis of EPM should be developed using South American isolates of Sarcocystis sp.

\section{Acknowledgements}

Luís Gondim and Rodrigo Soares are recipients of productivity fellowships from the National Council for Scientific and Technological Development (CNPq). Rogério de Jesus received a doctoral scholarship from the Coordination Office for the Improvement of Higher-Education Personnel (CAPES).

\section{References}

Acosta ICL, Soares RM, Mayorga LFSP, Alves BF, Soares HS, Gennari SM. Occurrence of tissue cyst forming coccidia in Magellanic penguins (Spheniscus magellanicus) rescued on the coast of Brazil. PLoS One 2018; 13(12): e0209007. http://dx.doi.org/10.1371/ journal.pone.0209007. PMid:30562391. 
Álvarez I, Wendel JF. Ribosomal ITS sequences and plant phylogenetic inference. Mol Phylogenet Evo/ 2003; 29(3): 417-434. http:// dx.doi.org/10.1016/S1055-7903(03)00208-2. PMid:14615184.

Antonello AM, Cadore GC, Pivoto FL, Camillo G, Braunig P, Sangioni LA, et al. Intra-uterine exposure of horses to Sarcocystis spp. antigens. Arq Bras Med Vet Zootec 2016; 68(2): 271-275. http://dx.doi.org/10.1590/1678-4162-8227.

Antonello AM, Pivoto FL, Camillo G, Braunig P, Sangioni LA, Pompermayer E, et al. Investigação de anticorpos contra Sarcocystis neurona e Sarcocystis cruzi em equinos. Arq Bras Med Vet Zootec 2015; 67(5): 1465-1468. http://dx.doi.org/10.1590/1678-4162-7374.

Barbosa L, Johnson CK, Lambourn DM, Gibson AK, Haman KH, Huggins JL, et al. A novel Sarcocystis neurona genotype XIII is associated with severe encephalitis in an unexpectedly broad range of marine mammals from the northeastern Pacific Ocean. Int J Parasitol 2015; 45(9-10): 595-603. http://dx.doi.org/10.1016/j.ijpara.2015.02.013. PMid:25997588.

Borges AMCM, Yeargan MR, Silva LG, Taques ÍIGG, Howe D, Aguiar DM. Antibodies against Sarcocystis neurona, Neospora spp., and Toxoplasma gondii in horses and mules from the Northern Pantanal Wetland of Brazil. J Equine Vet Sci 2017; 56: 19-25. http:// dx.doi.org/10.1016/j.jevs.2017.04.007.

Borges-Silva W, de Jesus RF, Ferreira R, Gondim LFP. Reactivity of Horse Sera to Antigens Derived From Sarcocystis falcatula-Like and Sarcocystis neurona. Front Vet Sci 2020; 7: 573016. http://dx.doi.org/10.3389/fvets.2020.573016. PMid:33240954.

Butcher M, Lakritz J, Halaney A, Branson K, Gupta GD, Kreeger J, et al. Experimental inoculation of domestic cats (Felis domesticus) with Sarcocystis neurona or S. neurona-like merozoites. Vet Parasitol 2002; 107(1-2): 1-14. http://dx.doi.org/10.1016/S03044017(02)00107-3. PMid:12072209.

Calderón A, Rodríguez V, Henao AG, Aguas LJ. Seroprevalence of Sarcocystis neurona in horses in montería (Córdoba, Colombia). Rev Udca Actual Divulg Cient 2014; 17(2): 453-459. http://dx.doi.org/10.31910/rudca.v17.n2.2014.250.

Casagrande RA, Cesar MO, Pena HFJ, Zwarg T, Teixeira RHF, Nunes ALV, et al. Ocorrência de Sarcocystis spp. em gambás (Didelphis aurita e Didelphis albiventris) em regiões do Estado de São Paulo, Brasil. Braz J Vet Res Anim Sci 2009; 46(2): 101-106. http://dx.doi. org/10.11606/issn.1678-4456.bjvras.2009.26755.

Cazarotto CJ, Balzan A, Grosskopf RK, Boito JP, Portella LP, Vogel FF, et al. Horses seropositive for Toxoplasma gondii, Sarcocystis spp. and Neospora spp.: possible risk factors for infection in Brazil. Microb Pathog 2016; 99: 30-35. http://dx.doi.org/10.1016/j. micpath.2016.07.016. PMid:27475033.

Cerqueira R. The distribution of Didelphis in South America (Polyprotodontia, Didelphidae). J Biogeogr 1985; 12(2): 135-145. http:// dx.doi.org/10.2307/2844837.

Cervantes FA, Arcangeli J, Hortelano-Moncada Y, Borisenko AV. DNA barcodes effectively identify the morphologically similar Common Opossum (Didelphis marsupialis) and Virginia Opossum (Didelphis virginiana) from areas of sympatry in Mexico. Mitochondrial DNA 2010;21(sup1 Suppl Suppl 1): 44-50. http://dx.doi.org/10.3109/19401736.2010.538051. PMid:21271858.

Cesar MO, Matushima ER, Zwarg T, de Oliveira AS, Sanches TC, Joppert AM, et al. Multilocus characterization of Sarcocystis falcatula-related organisms isolated in Brazil supports genetic admixture of high diverse SAG alleles among the isolates. Exp Parasitol 2018; 188: 42-49. http://dx.doi.org/10.1016/j.exppara.2018.03.004. PMid:29522766.

Clubb SL, Frenkel JK. Sarcocystis falcatula of opossums: transmission by cockroaches with fatal pulmonary disease in psittacine birds. J Parasitol 1992; 78(1): 116-124. http://dx.doi.org/10.2307/3283697. PMid:1738053.

Cutler TJ, MacKay RJ, Ginn PE, Greiner EC, Porter R, Yowell CA, et al. Are Sarcocystis neurona and Sarcocystis falcatula synonymous? A horse infection challenge. J Parasitol 1999; 85(2): 301-305. http://dx.doi.org/10.2307/3285638. PMid:10219313.

da Silva Stabenow C, Ederli NB, Lopes CW, de Oliveira FC. Didelphis aurita (Marsupialia: Didelphidae): a new host for Sarcocystis lindsayi (Apicomplexa: Sarcocystidae). J Parasitol 2012; 98(6): 1262-1265. http://dx.doi.org/10.1645/GE-3140.1. PMid:22571294.

Dame JB, MacKay RJ, Yowell CA, Cutler TJ, Marsh A, Greiner EC. Sarcocystis falcatula from passerine and psittacine birds: synonymy with Sarcocystis neurona, agent of equine protozoal myeloencephalitis. J Parasito/ 1995; 81(6): 930-935. http://dx.doi. org/10.2307/3284044. PMid:8544067.

de Jesus RF, Borges-Silva W, Bezerra TL, Gondim LQ, Uzêda RS, Gondim LFP. Serologic cross-reactivity between Sarcocystis neurona and Sarcocystis falcatula-like in experimentally infected Mongolian gerbils. Vet Parasito/ 2019; 276: 108962. http://dx.doi. org/10.1016/j.vetpar.2019.108962. PMid:31704559.

Dias CAR, Perini FA. Biogeography and early emergence of the genus Didelphis (Didelphimorphia, Mammalia). Zool Scr 2018; 47(6): 645-654. http://dx.doi.org/10.1111/zsc.12306.

Duarte PC, Daft BM, Conrad PA, Packham AE, Gardner IA. Comparison of a serum indirect fluorescent antibody test with two Western blot tests for the diagnosis of equine protozoal myeloencephalitis. J Vet Diagn Invest 2003; 15(1): 8-13. http://dx.doi. org/10.1177/104063870301500103. PMid:12580288.

Dubey J, Calero-Bernal R, Rosenthal B, Speer C, Fayer R. Sarcocystosis of animals and humans. Boca Raton, Flórida: CRC Press; 2016. 
Dubey JP, Davis SW, Speer CA, Bowman DD, de Lahunta A, Granstrom DE, et al. Sarcocystis neurona n. sp. (Protozoa: Apicomplexa), the etiologic agent of equine protozoal myeloencephalitis. J Parasitol 1991; 77(2): 212-218. http://dx.doi.org/10.2307/3283084. PMid:1901359.

Dubey JP, Garner MM, Stetter MD, Marsh AE, Barr BC. Acute Sarcocystis falcatula-like infection in a carmine bee-eater (Merops nubicus) and immunohistochemical cross reactivity between Sarcocystis falcatula and Sarcocystis neurona. J Parasito/ 2001 a; 87(4): 824-832. http://dx.doi.org/10.1645/0022-3395(2001)087[0824:ASFLII]2.0.CO;2. PMid:11534648.

Dubey JP, Howe DK, Furr M, Saville WJ, Marsh AE, Reed SM, et al. An update on Sarcocystis neurona infections in animals and equine protozoal myeloencephalitis (EPM). Vet Parasitol 2015a; 209(1-2): 1-42. http://dx.doi.org/10.1016/j.vetpar.2015.01.026. PMid:25737052.

Dubey JP, Kerber CE, Granstrom DE. Serologic prevalence of Sarcocystis neurona, Toxoplasma gondii, and Neospora caninum in horses in Brazil. J Am Vet Med Assoc 1999a; 215(7): 970-972. PMid:10511862.

Dubey JP, Kerber CE, Lindsay DS, Kasai N, Pena HF. The South American opossum, Didelphis marsupialis, from Brazil as another definitive host for Sarcocystis speeri Dubey and Lindsay, 1999. Parasitology 2000a; 121(Pt 6): 589-594. http://dx.doi.org/10.1017/ S003118200000682X. PMid:11155929.

Dubey JP, Lindsay DS, Hill D, Romand S, Thulliez P, Kwok OC, et al. Prevalence of antibodies to Neospora caninum and Sarcocystis neurona in sera of domestic cats from Brazil. J Parasitol 2002; 88(6): 1251-1252. http://dx.doi.org/10.1645/00223395(2002)088[1251:POATNC]2.0.CO;2. PMid:12537122.

Dubey JP, Lindsay DS, Kerber CE, Kasai N, Pena HF, Gennari SM, et al. First isolation of Sarcocystis neurona from the South American opossum, Didelphis albiventris, from Brazil. Vet Parasitol 2001b; 95(2-4): 295-304. http://dx.doi.org/10.1016/S03044017(00)00395-2. PMid:11223209.

Dubey JP, Lindsay DS, Rezende PC, Costa AJ. Characterization of an unidentified Sarcocystis falcatula-like parasite from the South American opossum, Didelphis albiventris from Brazil. J Eukaryot Microbiol 2000b; 47(6): 538-544. http://dx.doi. org/10.1111/j.1550-7408.2000.tb00087.x. PMid:11128705.

Dubey JP, Lindsay DS, Rosenthal BM, Kerber CE, Kasai N, Pena HF, et al. Isolates of Sarcocystis falcatula-like organisms from South American opossums Didelphis marsupialis and Didelphis albiventris from São Paulo, Brazil. J Parasitol 2001c; 8(6): 1449-1453. http://dx.doi.org/10.1645/0022-3395(2001)087[1449:iosflo]2.0.co;2. PMid:11780836.

Dubey JP, Lindsay DS, Venturini L, Venturini C. Characterization of Sarcocystis falcatula isolates from the Argentinian opossum, Didelphis albiventris. J Eukaryot Microbiol 2000c; 47(3): 260-263. http://dx.doi.org/10.1111/j.1550-7408.2000.tb00045.x. PMid:10847342.

Dubey JP, Lindsay DS. Isolation in immunodeficient mice of Sarcocystis neurona from opossum (Didelphis virginiana) faeces, and its differentiation from Sarcocystis falcatula. Int J Parasito/ 1998; 28(12): 1823-1828. http://dx.doi.org/10.1016/S0020-7519(98)001660. PMid:9925260.

Dubey JP, Lindsay DS. Sarcocystis speeri n. sp. (Protozoa: Sarcocystidae) from the opossum (Didelphis virginiana). J Parasitol 1999; 85(5): 903-909. http://dx.doi.org/10.2307/3285830. PMid:10577729.

Dubey JP, Rosenthal BM, Speer CA. Sarcocystis lindsayi n. sp. (Protozoa: Sarcocystidae) from the South American opossum, Didelphis albiventris from Brazil. J Eukaryot Microbio/ 2001d; 48(5): 595-603. http://dx.doi.org/10.1111/j.1550-7408.2001.tb00196.x. PMid:11596925.

Dubey JP, Speer CA, Bowman DD, Horton KM, Venturini C, Venturini L. Experimental transmission of Sarcocystis speeri Dubey and Lindsay, 1999 from the South American opossum (Didelphis albiventris) to the North American opossum (Didelphis virginiana). $J$ Parasitol 2000d; 86(3): 624-627. http://dx.doi.org/10.1645/0022-3395(2000)086[0624:ETOSSD]2.0.CO;2. PMid:10864267.

Dubey JP, Venturini L, Venturini C, Basso W, Unzaga J. Isolation of Sarcocystis falcatula from the South American opossum (Didelphis albiventris) from Argentina. Vet Parasito/ 1999b; 86(4): 239-244. http://dx.doi.org/10.1016/S0304-4017(99)00145-4. PMid:10536981 .

Dubey JP, Venturini L, Venturini MC, Speer CA. Isolation of Sarcocystis speeri Dubey and Lindsay, 1999 parasite from the South American opossum (Didelphis albiventris) from Argentina. J Parasitol 2000e; 86(1): 160-163. http://dx.doi.org/10.1645/00223395(2000)086[0160:IOSSDA]2.0.CO;2. PMid:10701583.

Dubey JP, Venturini MC, Venturini L, McKinney J, Pecoraro M. Prevalence of antibodies to Sarcocystis neurona, Toxoplasma gondii and Neospora caninum in horses from Argentina. Vet Parasito/ 1999c; 86(1): 59-62. http://dx.doi.org/10.1016/S0304-4017(99)001272. PMid:10489203.

Dubey JP, Verma SK, Dunams D, Calero-Bernal R, Rosenthal BM. Molecular characterization and development of Sarcocystis speeri sarcocysts in gamma interferon gene knockout mice. Parasitology 2015b; 142(13): 1555-1562. http://dx.doi.org/10.1017/ S0031182015001109. PMid:26303093. 
Ecco R, Luppi MM, Malta MCC, Araújo MR, Guedes RMC, Shivaprasad HL. An outbreak of sarcocystosis in psittacines and a pigeon in a zoological collection in Brazil. Avian Dis 2008; 52(4): 706-710. http://dx.doi.org/10.1637/8303-040408-Case.1. PMid:19166069.

Ellis JT, Morrison DA, Liddell S, Jenkins MC, Mohammed OB, Ryce C, et al. The genus Hammondia is paraphyletic. Parasitology 1999; 118(Pt 4): 357-362. http://dx.doi.org/10.1017/S0031182098003801. PMid:10340325.

Ellison SP, Greiner E, Dame JB. In vitro culture and synchronous release of Sarcocystis neurona merozoites from host cells. Vet Parasitol 2001; 95(2-4): 251-261. http://dx.doi.org/10.1016/S0304-4017(00)00391-5. PMid:11223205.

Fenger CK, Granstrom DE, Langemeier JL, Stamper S, Donahue JM, Patterson JS, et al. Identification of opossums (Didelphis virginiana) as the putative definitive host of Sarcocystis neurona. J Parasito/ 1995; 81(6): 916-919. http://dx.doi.org/10.2307/3284040. PMid:8544064.

Gallo SSM, Lindsay DS, Ederli NB, Matteoli FP, Venancio TM, de Oliveira FCR. Identification of opossums Didelphis aurita (WiedNeuweid, 1826) as a definitive host of Sarcocystis falcatula-like sporocysts. Parasitol Res 2018; 117(1): 213-223. http://dx.doi. org/10.1007/s00436-017-5695-4. PMid:29192336.

Gennari SM, Pena HFJ, Lindsay DS, Lopes MG, Soares HS, Cabral AD, et al. Prevalence of antibodies against Neospora spp. and Sarcocystis neurona in donkeys from northeastern Brazil. Rev Bras Parasito/ Vet 2016; 25(1): 109-111. http://dx.doi.org/10.1590/ S1984-29612016003. PMid:26982557.

Gjerde B, Vikøren T, Hamnes IS. Molecular identification of Sarcocystis halieti n. sp., Sarcocystis lari and Sarcocystis truncata in the intestine of a white-tailed sea eagle (Haliaeetus albicilla) in Norway. Int J Parasitol Parasites Wildl 2017; 7(1): 1-11. http://dx.doi. org/10.1016/j.ijppaw.2017.12.001. PMid:29270360.

Gjerde B. Molecular characterisation of Sarcocystis bovifelis, Sarcocystis bovini n. sp., Sarcocystis hirsuta and Sarcocystis cruzi from cattle (Bos taurus) and Sarcocystis sinensis from water buffaloes (Bubalus bubalis). Parasitol Res 2016; 115(4): 1473-1492. http:// dx.doi.org/10.1007/s00436-015-4881-5. PMid:26677095.

Gjerde B. Molecular characterisation of Sarcocystis rileyi from a common eider (Somateria mollissima) in Norway. Parasitol Res 2014; 113(9): 3501-3509. http://dx.doi.org/10.1007/s00436-014-4062-y. PMid:25082019.

Gjerde B. Phylogenetic relationships among Sarcocystis species in cervids, cattle and sheep inferred from the mitochondrial cytochrome c oxidase subunit I gene. Int J Parasitol 2013; 43(7): 579-591. http://dx.doi.org/10.1016/j.ijpara.2013.02.004. PMid:23542092.

Godoy SN, De Paula CD, Cubas ZS, Matushima ER, Catão-Dias JL. Occurrence of Sarcocystis falcatula in captive psittacine birds in Brazil. J Avian Med Surg 2009; 23(1): 18-23. http://dx.doi.org/10.1647/2008-006R.1. PMid:19530402.

Gomes FA, Jansen AM, Machado RZ, Jesus Pena HF, Fumagalli MJ, Silva A, et al. Serological evidence of arboviruses and coccidia infecting horses in the Amazonian region of Brazil. PLoS One 2019; 14(12): e0225895. http://dx.doi.org/10.1371/journal. pone.0225895. PMid:31830142.

Gondim LFP, Soares RM, Tavares AS, Borges-Silva W, de Jesus RF, Llano HAB, et al. Sarcocystis falcatula-like derived from opossum in Northeastern Brazil: in vitro propagation in avian cells, molecular characterization and bioassay in birds. Int J Parasitol Parasites Wildl 2019; 10: 132-137. http://dx.doi.org/10.1016/j.ijppaw.2019.08.008. PMid:31516824.

Gondim LSQ, Jesus RF, Ribeiro-Andrade M, Silva JCR, Siqueira DB, Marvulo MFV, et al. Sarcocystis neurona and Neospora caninum in Brazilian opossums (Didelphis spp.): molecular investigation and in vitro isolation of Sarcocystis spp. Vet Parasitol 2017; 243: 192-198. http://dx.doi.org/10.1016/j.vetpar.2017.07.002. PMid:28807293.

Granstrom DE, Dubey JP, Davis SW, Fayer R, Fox JC, Poonacha KB, et al. Equine protozoal myeloencephalitis: antigen analysis of cultured Sarcocystis neurona merozoites. J Vet Diagn Invest 1993; 5(1): 88-90. http://dx.doi.org/10.1177/104063879300500118. PMid:8466988.

Hammerschmitt ME, Henker LC, Lichtler J, da Costa FVA, Soares RM, Llano HAB, et al. First molecular characterization of Sarcocystis neurona causing meningoencephalitis in a domestic cat in Brazil. Parasitol Res 2020; 119(2): 675-682. http://dx.doi.org/10.1007/ s00436-019-06570-w. PMid:31901995.

Henker LC, Bandinelli MB, de Andrade CP, Bianchi MV, Sonne L, Driemeier D, et al. Pathological, immunohistochemical, and molecular findings of equine protozoal myeloencephalitis due to Sarcocystis neurona infection in Brazilian horses. Trop Anim Health Prod 2020; 52(6): 3809-3817. http://dx.doi.org/10.1007/s11250-020-02419-y. PMid:33011934.

Hillis DM, Dixon MT. Ribosomal DNA: molecular evolution and phylogenetic inference. Q Rev Biol 1991; 66(4): 411-453. http:// dx.doi.org/10.1086/417338. PMid:1784710.

Hillyer EV, Anderson MP, Greiner EC, Atkinson CT, Frenkel JK. An outbreak of Sarcocystis in a collection of psittacines. J Zoo Wildl Med 1991; 22(4): 434-445. 
Hoane JS, Gennari SM, DubeyJP, Ribeiro MG, Borges AS, Yai LE, et al. Prevalence of Sarcocystis neurona and Neospora spp. infection in horses from Brazil based on presence of serum antibodies to parasite surface antigen. Vet Parasitol 2006; 136 (2): $155-159$. http://dx.doi.org/10.1016/j.vetpar.2005.10.023. PMid:16310955.

Jankowski G, Adkesson MJ, Saliki JT, Cárdenas-Alayza S, Majluf P. Survey for Infectious Disease in the South American Fur Seal (Arctocephalus australis) Population at Punta San Juan, Peru. J Zoo Wildl Med 2015; 46(2): 246-254. http://dx.doi.org/10.1638/20140120.1. PMid:26056875.

Koch MDO, Laskoski LM, Aguiar DM, Silva BR, Régio RR, Ishikura Jl, et al. Detection of antibodies against Sarcocystis neurona, Neospora caninum and Toxoplasma gondii in horses, dogs and cat. Braz J Vet Res Anim Sci 2019; 56(2): e152918. http://dx.doi. org/10.11606/issn.1678-4456.bjvras.2019.152918.

Konradt G, Bianchi MV, Leite-Filho RV, da Silva BZ, Soares RM, Pavarini SP, et al. Necrotizing meningoencephalitis caused by Sarcocystis falcatula in bare-faced ibis (Phimosus infuscatus). Parasitol Res 2017; 116(2): 809-812. http://dx.doi.org/10.1007/s00436016-5341-6. PMid:27915419.

Kornacka A, Cybulska A, Bien J, Gozdzik K, Moskwa B. The usefulness of direct agglutination test, enzyme-linked immunosorbent assay and polymerase chain reaction for the detection of Toxoplasma gondii in wild animals. Vet Parasitol 2016; 228: 85-89. http:// dx.doi.org/10.1016/j.vetpar.2016.08.010. PMid:27692337.

Lemos B, Cerqueira R. Morphological differentiation in the white-eared opossum group (Didelphidae: Didelphis). J Mammal 2002; 83(2): 354-369. http://dx.doi.org/10.1644/1545-1542(2002)083<0354:MDITWE>2.0.CO;2.

Levine ND. The taxonomy of Sarcocystis (Protozoa, Apicomplexa) species. J Parasitol 1986; 72(3): 372-382. http://dx.doi. org/10.2307/3281676. PMid:3091802.

Lindsay DS, Blagburn BL, Braund KG. Sarcocystis spp. and sarcocystosis. BAM 1995; 5(3): 249-254.

Lindsay DS, Mitchell SM, Vianna MC, Dubey JP. Sarcocystis neurona (Protozoa: Apicomplexa): description of oocysts, sporocysts, sporozoites, excystation, and early development. J Parasitol 2004; 90(3): 461-465. http://dx.doi.org/10.1645/GE-230R. PMid:15272465.

Lombardo de Barros CS, de Barros SS, dos Santos MN. Equine protozoal myeloencephalitis in southern Brazil. Vet Rec 1986; 119(11): 283-284. http://dx.doi.org/10.1136/vr.119.11.283. PMid:3776029.

Lucio BM, Minuzzi CE, de Avila NC, Tondo LAS, Vogel FS, Kommers GD, et al. Natural occurring muscular sarcocysts in urban domestic cats (Felis catus) Without Sarcocystis-Associated disease. Acta Parasito/ 2021; 66(1): 129-135. http://dx.doi.org/10.1007/ s11686-020-00262-7. PMid:32789799.

Macruz R, Lenci O, Ishizuka MM, Miguel O, Cunha RAF. Toxoplasmose em eqüinos PSI. Estudo sorológico. Rev Fac Med Vet Zootec Univ São Paulo 1975; 12(1): 277-282. http://dx.doi.org/10.11606/issn.2318-3659.v12i1p277-282.

Maljkovic Berry I, Melendrez MC, Bishop-Lilly KA, Rutvisuttinunt W, Pollett S, Talundzic E, et al. Next generation sequencing and bioinformatics methodologies for infectious disease research and public health: approaches, applications, and considerations for development of laboratory capacity. J Infect Dis 2020; 221(Suppl 3): S292-S307. http://dx.doi.org/10.1093/infdis/jiz286. PMid:31612214.

Mansfield LS, Mehler S, Nelson K, Elsheikha HM, Murphy AJ, Knust B, et al. Brown-headed cowbirds (Molothrus ater) harbor Sarcocystis neurona and act as intermediate hosts. Vet Parasitol 2008; 153(1-2): 24-43. http://dx.doi.org/10.1016/j. vetpar.2007.12.016. PMid:18342449.

Marsh AE, Barr BC, Tell L, Bowman DD, Conrad PA, Ketcherside C, et al. Comparison of the internal transcribed spacer, ITS-1, from Sarcocystis falcatula isolates and Sarcocystis neurona. J Parasitol 1999; 85(4): 750-757. http://dx.doi.org/10.2307/3285758. PMid:10461964.

Marsh AE, Barr BC, Tell L, Koski M, Greiner E, Dame J, et al. In vitro cultivation and experimental inoculation of Sarcocystis falcatula and Sarcocystis neurona merozoites into budgerigars (Melopsittacus undulatus). J Parasitol 1997; 83(6): 1189-1192. http://dx.doi. org/10.2307/3284386. PMid:9406803.

Masri MD, Alda JL, Dubey JP. Sarcocystis neurona-associated ataxia in horses in Brazil. Vet Parasitol 1992; 44(3-4): 311-314. http:// dx.doi.org/10.1016/0304-4017(92)90128-V. PMid:1466140.

Medina CE, Oliver OJ. Mieloencefalitis protozoica equina en colombia. reporte de caso. Rev Med Vet Zootec (Bogota) 2003; 50(1): 6-9.

Meneses IDS, Andrade MR, Uzêda RS, Bittencourt MV, Lindsay DS, Gondim LF. Frequency of antibodies against Sarcocystis neurona and Neospora caninum in domestic cats in the state of Bahia, Brazil. Rev Bras Parasito/ Vet 2014; 23(4): 526-529. http://dx.doi. org/10.1590/s1984-29612014080. PMid:25517534.

Miller MA, Conrad PA, Harris M, Hatfield B, Langlois G, Jessup DA, et al. A protozoal-associated epizootic impacting marine wildlife: mass-mortality of southern sea otters (Enhydra lutris nereis) due to Sarcocystis neurona infection. Vet Parasitol 2010; 172(3-4): 183-194. http://dx.doi.org/10.1016/j.vetpar.2010.05.019. PMid:20615616. 
Monteiro RM, Keid LB, Richtzenhain LJ, Valadas SY, Muller G, Soares RM. Extensively variable surface antigens of Sarcocystis spp. infecting Brazilian marsupials in the genus Didelphis occur in myriad allelic combinations, suggesting sexual recombination has aided their diversification. Vet Parasitol 2013; 196(1-2): 64-70. http://dx.doi.org/10.1016/j.vetpar.2013.01.019.

Moré G, Monina M, Girotti G, Idiart J, Venturini L, Venturini MC. Descripción de un caso de mieloencefalitis equina por protozoos (EPM) en Argentina. Analecta Vet 2019; 39(1): 32-36. https://doi.org/10.24215/15142590e035.

Moré G, Vissani A, Pardini L, Monina M, Muriel M, Howe D, et al. Seroprevalence of Sarcocystis neurona and its association with neurologic disorders in Argentinean horses.J Equine Vet Sci 2014; 34(9): 1051-1054. http://dx.doi.org/10.1016/j.jevs.2014.06.002.

Morrison DA, Bornstein S, Thebo P, Wernery U, Kinne J, Mattsson JG. The current status of the small subunit rRNA phylogeny of the coccidia (Sporozoa). Int J Parasitol 2004; 34(4): 501-514. http://dx.doi.org/10.1016/j.ijpara.2003.11.006. PMid:15013740.

Morrison DA, Ellis JT. Effects of nucleotide sequence alignment on phylogeny estimation: a case study of 18S rDNAs of apicomplexa. Mol Biol Evol 1997; 14(4): 428-441. http://dx.doi.org/10.1093/oxfordjournals.molbev.a025779. PMid:9100373.

Mugridge NB, Morrison DA, Jakel T, Heckeroth AR, Tenter AM, Johnson AM. Effects of sequence alignment and structural domains of ribosomal DNA on phylogeny reconstruction for the protozoan family sarcocystidae. Mol Biol Evol 2000; 17(12): 1842-1853. http://dx.doi.org/10.1093/oxfordjournals.molbev.a026285. PMid:11110900.

Mugridge NB, Morrison DA, Johnson AM, Luton K, Dubey JP, Votýpka J, et al. Phylogenetic relationships of the genus Frenkelia: a review of its history and new knowledge gained from comparison of large subunit ribosomal ribonucleic acid gene sequences. Int J Parasitol 1999; 29(6): 957-972. http://dx.doi.org/10.1016/S0020-7519(99)00062-4. PMid:10480733.

Ogedengbe ME, Ogedengbe JD, Whale JC, Elliot K, Juárez-Estrada MA, Barta JR. Molecular phylogenetic analyses of tissue coccidia (Sarcocystidae; Apicomplexa) based on nuclear 18S rDNA and mitochondrial COI sequences confirms the paraphyly of the genus Hammondia. Parasitology Open 2016; 2: e2. http://dx.doi.org/10.1017/pao.2015.7.

Olias P, Olias L, Lierz M, Mehlhorn H, Gruber AD. Sarcocystis calchasi is distinct to Sarcocystis columbae sp. nov. from the wood pigeon (Columba palumbus) and Sarcocystis sp. from the sparrowhawk (Accipiter nisus). Vet Parasitol 2010; 171 (1-2): 7-14. https:// doi.org/10.1016/j.vetpar.2010.03.021.

Oliveira CMC, Oliveira PB, Albuquerque GR, Gondim LFP. Serologic reactivity of canine sera to Sarcocystis neurona and Sarcocystis cruzi antigens. Vet Parasitol Reg Stud Reports 2020; 21: 100439. http://dx.doi.org/10.1016/j.vprsr.2020.100439. PMid:32862892.

Oliveira S, Silva NQB, Silveira I, Labruna MB, Gennari SM, Pena HFJ. Occurrences of antibodies against Toxoplasma gondii, Neospora spp., and Sarcocystis neurona in horses and dogs in the municipality of Pauliceia, São Paulo, Brazil. Braz J Vet Res Anim Sci 2017; 54(3): 277-282. http://dx.doi.org/10.11606/issn.1678-4456.bjvras.2017.123956.

Onuma SS, Melo ALT, Kantek DLZ, Crawshaw-Junior PG, Morato RG, May-Junior JA, et al. Exposure of free-living jaguars to Toxoplasma gondii, Neospora caninum and Sarcocystis neurona in the Brazilian Pantanal. Rev Bras Parasitol Vet 2014; 23(4): 547553. http://dx.doi.org/10.1590/s1984-29612014077. PMid:25517539.

Paixão TA, Rêgo IOP, Santos RL. Anti-Sarcocystis neurona immunostaining associated with equine protozoal myeloencephalitis in Brazil. Cienc Rural 2007; 37(6): 1820-1823. http://dx.doi.org/10.1590/S0103-84782007000600052.

Pentinsaari M, Salmela H, Mutanen M, Roslin T. Molecular evolution of a widely-adopted taxonomic marker (COI) across the animal tree of life. Sci Rep 2016; 6(1): 35275. http://dx.doi.org/10.1038/srep35275. PMid:27734964.

Pivoto FL, de Macedo AG Jr, da Silva MV, Ferreira FB, Silva DA, Pompermayer E, et al. Serological status of mares in parturition and the levels of antibodies (IgG) against protozoan family Sarcocystidae from their pre colostral foals. Vet Parasitol 2014; 199(1 2): 107-111. http://dx.doi.org/10.1016/j.vetpar.2013.10.001. PMid:24183649.

Portella LP, Cadore GC, Sangioni LA, Pellegrini LFV, Fighera R, Ramos F, et al. Antibodies against Apicomplexa protozoa and absence sarcocysts in heart tissues from horses in southern Brazil. Rev Bras Parasitol Vet 2017; 26(1): 100-103. http://dx.doi. org/10.1590/s1984-29612016068. PMid:28327879.

Prakas P, Kutkienè L, Butkauskas D, Sruoga A, Žalakevičius M. Molecular and morphological investigations of Sarcocystis corvusi sp. nov. from the jackdaw (Corvus monedula). Parasitol Res 2013; 112(3): 1163-1167. https://doi.org/10.1007/s00436-012-3247-5.

Prakas P, Kutkienè L, Sruoga A, Butkauskas D. Sarcocystis sp. from the herring gull (Larus argentatus) identity to Sarcocystis wobeseri based on cyst morphology and DNA results. Parasitol Res 2011; 109(6): 1603-1608. http://dx.doi.org/10.1007/s00436011-2421-5. PMid:21597959.

PubMed. National Library of Medicine [online]. Bethesda, MD: NIH; 2021 [cited 2021 February] Available from: https://pubmed. ncbi.nlm.nih.gov/

PubMed. National Library of Medicine [online]. Bethesda, MD: NIH; 2020. [cited 2020 July]. Available from: https://pubmed.ncbi. nIm.nih.gov/ 
Reed SM, Howe DK, Morrow JK, Graves A, Yeargan MR, Johnson AL, et al. Accurate antemortem diagnosis of equine protozoal myeloencephalitis (EPM) based on detecting intrathecal antibodies against Sarcocystis neurona using the SnSAG2 and SnSAG4/3 ELISAs.J Vet Intern Med 2013; 27(5): 1193-1200. http://dx.doi.org/10.1111/jvim.12158. PMid:24033423.

Rejmanek D, Miller MA, Grigg ME, Crosbie PR, Conrad PA. Molecular characterization of Sarcocystis neurona strains from opossums (Didelphis virginiana) and intermediate hosts from Central California. Vet Parasitol 2010; 170(1-2): 20-29. http://dx.doi.org/10.1016/j. vetpar.2009.12.045. PMid:20226596.

Ribeiro MJM, Rosa MHF, Bruhn FRP, Garcia AM, Rocha CMBM, Guimarães AM. Seroepidemiology of Sarcocystis neurona, Toxoplasma gondii and Neospora spp. among horses in the south of the state of Minas Gerais, Brazil. Rev Bras Parasitol Vet 2016; 25(2): 142150. http://dx.doi.org/10.1590/S1984-29612016029. PMid:27334814.

Sato AP, Vaz FF, Konell AL, Koch MO, Ferreira RF, Sipinski EAB, et al. Survey of Toxoplasma gondii, Neospora caninum and Sarcocystis neurona antibodies in wild red-tailed Amazon parrots (Amazona brasiliensis). Rev Bras Parasitol Vet 2020; 29(1): e017519. http:// dx.doi.org/10.1590/s1984-29612019107. PMid:32049146.

SciELO. [online]. Scielo: São Paulo; 2020. [cited 2020 July]. Available from: https://scielo.org/

SciELO. [online]. Scielo: São Paulo; 2021. [cited 2021 February]. Available from: https://scielo.org/

Scopus. [online]. Amsterdam: Elsevier; 2020. [cited 2020 July]. Available from: https://www.elsevier.com/pt-br/solutions/scopus.

Scopus. [online]. Amsterdam: Elsevier; 2021. [cited 2021 February] Available from: https://www.elsevier.com/pt-br/solutions/ scopus.

Siegal-WillottJL, Pollock CG, Carpenter JW, Nietfeld J. Encephalitis caused by Sarcocystis falcatula-like organisms in a white cockatoo (Cacatua alba). J Avian Med Surg 2005; 19(1): 19-24. http://dx.doi.org/10.1647/2004-005.

Smith JH, Meier JL, Neill PJ, Box ED. Pathogenesis of Sarcocystis falcatula in the budgerigar. I. Early pulmonary schizogony. Lab Invest 1987a; 56(1): 60-71. PMid:3099083.

Smith JH, Meier JL, Neill PJ, Box ED. Pathogenesis of Sarcocystis falcatula in the budgerigar. II. Pulmonary pathology. Lab Invest 1987b; 56(1): 72-84. PMid:3099084.

Sousa LCC, Gontijo CMF, Lacorte GA, Meireles SN, Silva AP, Fonseca CG. Molecular characterization of an opossum Didelphis albiventris (Marsupialia: Didelphidae) population in an urban fragment of the Brazilian Atlantic rainforest and support to species barcode identification. Genet Mol Res 2012; 11(3): 2487-2496. http://dx.doi.org/10.4238/2012.June.15.4. PMid:22782626.

Spohr KAH, Borges AMCM, Ribeiro TMP, Jayme VS, Godoy I, Nakazato L, et al. Fatores de risco associados à prevalência de anticorpos anti-Sarcocystis neurona, Neospora spp. e Toxoplasma gondii em equinos de Roraima, Amazônia. Pesq Vet Bras 2018; 38(7): 1337-1343. http://dx.doi.org/10.1590/1678-5150-pvb-5127.

Stabenow CS, De Oliveira FC, Albuquerque GR, Lopes CW. Sarcocystis lindsayi-like (Apicomplexa: Sarcocystinae) of the opossum (Didelphis aurita) from Southeastern Brazil. Rev Bras Parasitol Vet 2008; 17(Suppl 1): 342-344. PMid:20059875.

Suedmeyer WK, Bermudez AJ, Barr BC, Marsh AE. Acute pulmonary Sarcocystis falcatula-like infection in three Victoria crowned pigeons (Goura victoria) housed indoors. J Zoo Wildl Med 2001; 32(2): 252-256. http://dx.doi.org/10.1638/10427260(2001)032[0252:apsfli]2.0.c0;2. PMid:12790430.

Tanhauser SM, Yowell CA, Cutler TJ, Greiner EC, MacKay RJ, Dame JB. Multiple DNA markers differentiate Sarcocystis neurona and Sarcocystis falcatula. J Parasitol 1999; 85(2): 221-228. http://dx.doi.org/10.2307/3285623. PMid:10219299.

Valadas S, Gennari SM, Yai LE, Rosypal AC, Lindsay DS. Prevalence of antibodies to Trypanosoma cruzi, Leishmania infantum, Encephalitozoon cuniculi, Sarcocystis neurona, and Neospora caninum in Capybara, Hydrochoerus hydrochaeris, from São Paulo State, Brazil.J Parasitol 2010; 96(3): 521-524. http://dx.doi.org/10.1645/GE-2368.1. PMid:20020808.

Valadas SY, da Silva JI, Lopes EG, Keid LB, Zwarg T, de Oliveira AS, et al. Diversity of Sarcocystis spp shed by opossums in Brazil inferred with phylogenetic analysis of DNA coding ITS1, cytochrome B, and surface antigens. Exp Parasitol 2016; 164: 71-78. http://dx.doi.org/10.1016/j.exppara.2016.02.008. PMid:26905780.

Valença SRFA, Ribeiro-Andrade M, Moré G, Albuquerque PPF, Pinheiro JW Jr, Mota RA. Low prevalence of infection by Sarcocystis neurona in horses from the State of Alagoas, Brazil. Rev Bras Parasito/ Vet 2019; 28(2): 298-302. http://dx.doi.org/10.1590/s198429612019027. PMid:31188947.

Verma SK, Trupkiewicz JG, Georoff T, Dubey JP. Molecularly confirmed acute, fatal Sarcocystis falcatula infection in the rainbow lorikeets (Trichoglossus moluccanus) at the Philadelphia Zoo. J Parasito/ 2018; 104(6): 710-712. http://dx.doi.org/10.1645/18-78. PMid:30091944.

Villar D, Kramer M, Howard L, Hammond E, Cray C, Latimer K. Clinical presentation and pathology of sarcocystosis in psittaciform birds: 11 cases. Avian Dis 2008; 52(1): 187-194. http://dx.doi.org/10.1637/8104-090207-Case. PMid:18459322. 
Watthanakaiwan V, Sukmak M, Hamarit K, Kaolim N, Wajjwalku W, Muangkram Y. Molecular characterization of the ribosomal DNA unit of Sarcocystis singaporensis, Sarcocystis zamani and Sarcocystis zuoi from rodents in Thailand. J Vet Med Sci 2017; 79(8): 1412-1418. http://dx.doi.org/10.1292/jvms.16-0086. PMid:28701623.

Web of Science. [online]. Clarivate Analytics; 2020. [cited 2020 July]. Available from: http://webofknowledge.com/WOS Web of Science. [online]. Clarivate Analytics; 2021. [cited 2021 February]. Available from: http://webofknowledge.com/WOS

Wendte JM, Miller MA, Nandra AK, Peat SM, Crosbie PR, Conrad PA, et al. Limited genetic diversity among Sarcocystis neurona strains infecting southern sea otters precludes distinction between marine and terrestrial isolates. Vet Parasito/ 2010; 169(1-2): 37-44. http://dx.doi.org/10.1016/j.vetpar.2009.12.020. PMid:20071081.

Wünschmann A, Rejmanek D, Conrad PA, Hall N, Cruz-Martinez L, Vaughn SB, et al. Natural fatal Sarcocystis falcatula infections in free-ranging eagles in North America. J Vet Diagn Invest 2010; 22(2): 282-289. http://dx.doi.org/10.1177/104063871002200222. PMid:20224094.

Wünschmann A, Rejmanek D, Cruz-Martinez L, Barr BC. Sarcocystis falcatula-associated encephalitis in a free-ranging great horned owl (Bubo virginianus). J Vet Diagn Invest 2009; 21(2): 283-287. http://dx.doi.org/10.1177/104063870902100223. PMid:19286517.

Zeng W, Sun L, Xiang Z, Li N, Zhang J, He Y, et al. Morphological and molecular characteristics of Sarcocystis bertrami from horses and donkeys in China. Vet Parasitol 2018; 252: 89-94. http://dx.doi.org/10.1016/j.vetpar.2018.01.024. PMid:29559158.. 